\title{
Influencias de la teoría política y jurídica de Santo Tomás de Aquino en el Estado contemporáneo
}

\author{
Influences of Saint Thomas Aquinas' Political \\ and Legal Theory on the Contemporary State
}

Francisco Javier RUIZ BURSÓN

Universidad de Sevilla

fjruibur@hotmail.com

Resumen: La trascendencia de Santo Tomás de Aquino en la historia de la filosofía resulta innegable. Sin embargo, aún se encuentra pendiente un estudio sistemático de sus aportaciones a los presupuestos básicos del Estado contemporáneo, en su triple cualidad de democrático, social y de derecho. En el presente artículo se pretende realizar una aproximación a la cuestión, la cual huye tanto de los fáciles anacronismos históricos como del falso tópico de un tomismo legitimador de fórmulas absolutistas o autoritarias.

Palabras clave: Estado social y democrático de derecho, bien común, ley natural, derechos humanos, contrato social, división de poderes, soberanía popular.

\begin{abstract}
The significance of Saint Thomas Aquinas in the history of philosophy is hardly deniable. Yet, a thorough analysis of his contribution to the basic assumptions of the contemporary democratic and social state, based on the rule of law, remains to be done. This essay provides an approach to such question, avoiding both simplistic anachronism and the cliché a of Thomism justifying authoritarian or absolutist rule.
\end{abstract}

Keywords: Welfare State, Democratic State, commonweal, natural law, human rights, social contract, division of powers, popular sovereignty.

\section{INTRODUCCIÓN}

A primera vista, el título del presente artículo puede parecer una auténtica contradicción. No cabe duda de que la distancia temporal y el contexto socio-político en el que se desarrolló la vida del Aquinate -siglo XIII-, dista mucho de la eclosión del Estado de derecho -fines del siglo XVIII- y de la consolidación de las aspiraciones democráticas y sociales en el ámbito constitucional -siglo XX-.

Sin embargo, no debe olvidarse una realidad obvia: los regímenes políticos, así como los sistemas filosóficos que los sustentan, no nacen como rea- 
lidades espontáneas sin raíces históricas ${ }^{1}$. No cabe duda de que toda nueva articulación social y política contiene un germen de continuidad -y otro de ruptura en el que se insiste especialmente para justificar la nueva legitimidad frente al orden instituido- con las estructuras que le preceden ${ }^{2}$.

Bien sea como modelo inspirador, bien como realidad que debe ser superada en sus defectos, los distintos momentos históricos muestran una evidente conexión con los anteriores, sin los cuales no podrían haber surgido. También se puede identificar, con un poco de perspicacia, la existencia de un conjunto de ideas-fuerza como auténticos lugares comunes que se repiten una y otra vez en las distintas épocas. En el fondo, todo ello no es más que la expresión de dos elementos inherentes a toda realidad antropológica: una naturaleza inmutable que se refleja en sus aspiraciones más profundas, por un lado, y, del otro, el carácter histórico y contingente inherente a la temporalidad de la existencia humana. Ambos rasgos se encuentran en una tensión dialéctica -en el sentido de la filosofía griega- que se manifiesta en la experiencia de ruptura y continuidad que ofrece la historia del pensamiento político.

Uno de los objetivos del presente trabajo es demostrar, mediante un adecuado estudio de las fuentes, que la extendida opinión de que la filosofía política de Santo Tomás de Aquino resulta trasnochada e inútil en la actualidad constituye un falso tópico y, por tanto, evidencia una falta de espíritu crítico por parte de quienes se encuentran cómodamente instalados en el pensamiento de lo «políticamente correcto».

La situación de crisis que la democracia constitucional representativa padece en el momento presente, con el auge de los populismos, la amenaza de la corrupción y el cáncer de la demagogia, exige una reflexión acerca de en qué punto del camino nos hemos equivocado o, de forma más precisa, sobre cuáles son los elementos del sistema vigente que han dejado de funcionar para que se cuestione la bondad de un modelo de convivencia que, por haber alcanzado altas cotas de paz y prosperidad en buena parte del planeta, ha querido ser emulada por quienes no disfrutaban del mismo.

1 PÉRez Luño, A. E., La Filosofía del Derecho en perspectiva bistórica, Servicio de Publicaciones Universidad de Sevilla, Sevilla, 2009, p. 86: «... la historia no da saltos en el vacío, ni es una mera yuxtaposición de períodos separados entre sí como compartimentos estancos. La historia de los conceptos jurídicos y políticos... no se agota en el dato efímero en el que se produce su plasmación, sino que se asienta en el espesor de la experiencia del pasado».

2 Etxebarria, X., Derechos bumanos y cristianismo. Aproximación hermenéutica, Universidad de Deusto, Bilbao, 1999, p. 35. 
Para afrontar este decisivo reto, resulta imprescindible una vuelta a las fuentes del pensamiento occidental en cuyo seno se pergeñaron estos ideales. Si el Estado social y democrático de derecho pudo surgir en Occidente, ello fue debido a una elaboración previa realizada por el pensamiento filosófico y la actividad socio-económica. El iter propuesto consiste en reencontrar nuevos caminos a través del análisis de los principios clásicos que dieron origen a lo que se ha venido en llamar el «Estado constitucional democráctico»³.

Del mismo modo que se debe huir de una apriorística animadversión al estudio de la filosofía tomista respecto a su aplicación a los problemas políticos actuales, por constituir un prejuicio ideológico más que una afirmación filosóficamente argumentada, también debemos rechazar el extremo opuesto.

Considerar que la obra del Doctor Angélico se puede transmutar sin más a la realidad actual, como si se tratara de una piedra filosofal infalible, constituye un error de idéntico calibre al anteriormente apuntado. El espíritu del Aquinate partió del análisis de la realidad concreta para aportar, desde parámetros flexibles y racionales, soluciones a los problemas del ser humano en su vida cotidiana. Por ello, la aplicación de Santo Tomás debe tener en cuenta las nuevas situaciones político-jurídicas nacidas a partir del siglo XVIII, con el fin de intentar conseguir una difícil -pero imprescindible- síntesis entre el pensamiento clásico y la Modernidad, del mismo modo que el ilustre dominico llevó a cabo una extraordinaria conciliación entre la fe cristiana y el aristotelismo ${ }^{4}$.

En consecuencia, resulta indispensable evitar el peligro de anacronismo en la interpretación de la obra del Aquinate. Hemos de tener en cuenta que

3 Esta fórmula ha sido definida por Rhonheimer, M., «Perché una filosofia politica? Elementi istorici per una risposta», Acta Philosophica, vol. 1, fasc. 2 (1992), p. 246: «Sin embargo, la polis moderna no es simplemente 'democracia'; es 'democracia constitucional' o 'estado constitucional democrático': el poder de la mayoría es sometido al derecho y limitado por el derecho, y la denominada 'neutralidad' del estado se basa en en una neta no-neutralidad respecto a aquellos valores fundamentales que forman el acuerdo constitucional, principalmente los 'derechos del hombre'».

4 Poole, D., «Derecho, razón y pasión en la ley natural», Ius Canonicum, n. 96 (2008), p. 544: «... entendemos que el Aquinate recoge en una síntesis admirable la tradición filosófica precedente, tanto pagana como religiosa, combinando la filosofía griega con lo mejor de los padres de la Iglesia... Por otra parte, Santo Tomás interpreta, de un modo que todavía no ha sido superado, el pensamiento de Aristóteles, a quien puede considerarse fundador de la filosofía moral de Occidente»; y Sigmund, P. «Law and Politics», en AA.VV. (Kretzmann, N. y Sump. E. [eds.]), The Cambridge Companion to Aquinas, Cambridge University Press, Cambridge, 1999, p. 218: «Aquino combina la tradición, la Escritura, la práctica contemporánea y el método filosófico aristotélico para producir una duradera e influyente 'síntesis tomista' sobre la política y la teoría legal». 
muchos de los conceptos utilizados por este autor en sus obras no son equivalentes a lo que entendemos en la actualidad bajo el mismo nombre 5 . Valgan como ejemplo los términos «democracia», «príncipe» o «gobierno monárquico», que se encuentran cargados de nuevas connotaciones semánticas $-y$ prácticas- ignoradas en el siglo XIII. Partiendo de dicha premisa, el objetivo de este trabajo es bucear en las afirmaciones del Doctor Angélico para comprobar si muestra puntos de conexión con el Estado constitucional moderno y, caso afirmativo, examinar las aportaciones que pueden ser aplicadas, en clave de solución, a los problemas actuales.

El otro polo de la cuestión viene marcado por el concepto de Estado social y democrático de derecho, consagrado en numerosos textos constitucionales ${ }^{6}$. En el mismo se pueden distinguir tres corrientes distintas que han confluido en su formación. Para exponerlas, seguiremos un orden cronológico.

En primer lugar aparece el «Estado de derecho» como contraposición a los regímenes de las monarquías absolutas consolidados durante los siglos XVII y XVIII. Las revoluciones liberales propugnan un nuevo Estado que no esté subordinado a la arbitraria voluntad del monarca -la frase del Luis XIV, «el Estado soy yo», es el paradigma del Antiguo Régimen-, sino que se encuentre sometido a ciertos límites, entre los cuales podemos destacar el imperio de la ley, la división de poderes y el respeto a los derechos humanos.

El Estado democrático entiende que la legitimación de los poderes políticos reside en la voluntad de sus ciudadanos, expresada en elecciones libres. Para su construcción resultaron imprescindibles conceptos como la soberanía popular o el contrato social y su origen histórico se encuentra en las luchas protagonizadas, durante el siglo XIX y principios del XX, por movimientos que pretendían el paso del sistema del sufragio censitario -que sólo reconocía el derecho al voto a los propietarios con un determinado nivel de renta- a otro, de carácter universal, en el participaran todas las personas mayores de edad con independencia de su capacidad económica o sexo.

El último en consolidarse fue el Estado social, cuya plena implantación tuvo lugar tras el fin de la Segunda Guerra Mundial. El mismo se caracteriza

5 Widow, J. A., «Escritos políticos de Santo Tomás de Aquino», en Estudios Políticos, n. ${ }^{\circ} 57$ (1995), pp. 347-348.

6 A los efectos del estudio de estos conceptos y su proceso de decantación histórica, resulta especialmente instructiva la lectura de PÉREZ Luño, A. E., Derechos Humanos, Estado de Derecho y Constitución, Tecnos, Madrid, 2010, pp. 218-251, y Ortiz Sánchez, M. y PÉrez Pino, V., Diccionario furídico Básico, Tecnos, Madrid, 2012, p. 158. 
por la exigencia de intervención de la autoridad estatal para proveer a los ciudadanos de determinados bienes públicos, entre los que destacan la enseñanza, la atención sanitaria y protección social frente a contingencias laborales. Asimismo, en su base encontramos determinados instrumentos filosóficos y jurídicos como el principio de justicia distributiva y la función social de la propiedad privada.

Como acertadamente señala BOBBIO, cada uno de estos modelos responde a una generación diferente de derechos humanos que disfrutan de su peculiar idiosincrasia ${ }^{7}$. El Estado de derecho implica el reconocimiento a los derechos civiles, que excluyen la actuación del Estado en determinadas esferas del individuo. El Estado democrático conlleva la consagración de los derechos políticos de todos los ciudadanos a intervenir en los asuntos públicos y en las decisiones que afectan al interés general. Y, por último, el Estado social es un trasunto de los derechos económicos y sociales que requieren la implicación activa de los poderes públicos en la mejora de las condiciones de vida.

Partiendo de estos pilares, procedemos a estructurar este trabajo en tres apartados distintos dedicados a cada uno de los conceptos de Estado en relación con los escritos de Santo Tomás de Aquino. Por último, expondremos las conclusiones que se derivan de cada uno de estos capítulos.

$\mathrm{Si}$ bien es cierto que son varios los libros donde el Aquinate desarrolla sus teorías de carácter político y jurídico, en el presente artículo nos centraremos en la Summa Theologica y en De Regimine Principum. Escogemos la primera porque constituye su obra de madurez donde se condensa el resultado de sus reflexiones contenidas en sus textos anteriores, y la última en tanto constituye un tratado sobre el gobierno político ${ }^{8}$.

Como punto final de esta introducción, haremos una breve exposición sobre las fuentes filosóficas que utiliza el Doctor Angélico en su doctrina sobre el Estado.

$\mathrm{Al}$ respecto, resulta incuestionable que las citas giran en torno a dos autoridades: por un lado, el pensamiento de Aristóteles reflejado en su obra $D e$

7 Bobbio, N., El tiempo de los derechos (trad. R. de A. Roig), Sistema, Madrid, 1991, pp. 70-71.

8 Beuchot, M., «Santo Tomás de Aquino: del Gobierno de los Príncipes», Revista Española de Filosofía Medieval (2005), pp. 101-102, apunta que De Regimine Principum sólo fue redactada por Santo Tomás en su libro I y los primeros cuatro capítulos del libro II, correspondiendo el resto -si bien basándose en los apuntes del maestro- a su discípulo Tolomeo de Lucca. En cuanto a las más recientes aportaciones sobre la autoría de dicha obra, vid. FInNIs, J., Aquinas. Moral, Political and Legal Theory, Oxford University Press, Oxford, 1998, p. 254, letra d. 
la Política, y, del otro, en las enseñanzas de la Patrística cristiana, con especial referencia a San Agustín.

Respecto a la corriente aristotélica, COPLESTON defiende que, si bien la misma ejerce una clara influencia -como se aprecia, por ejemplo, en su exposición de las formas de gobierno-, ésta no fue decisiva9 ${ }^{9}$ El jesuita británico afirma que, de haber seguido de una forma literal la enseñanza del Estagirita, Santo Tomás habría defendido un modelo de Estado donde el ciudadano quedaría absolutamente subordinado al poder político, en tanto que sería una parte de la polis absorbida por el todo. Sin embargo, la posición del Aquinate es otra, ya que reclama ámbitos de actuación de la persona -y de otras organizaciones intermedias, como la familia- que deben quedar resguardados del poder del príncipe. Esta peculiaridad no se debe solo a que el régimen político de las monarquías medievales fuera diferente al de las ciudades-Estado de la Antigüedad, sino a razones más profundas. La antropología tomista incorpora una visión cristiana que exige el respeto a la persona, como ser de incalculable valor llamado a fines sobrenaturales que exceden de la competencia del poder político $^{10}$. En este extremo ya encontramos un claro precedente de la fundamentación teológica de la dignidad humana y sus correlativos derechos.

Sin embargo, tampoco cabe encontrar una completa analogía entre el pensamiento del Obispo de Hipona ${ }^{11}-\mathrm{y}$ de San Isidoro o San Ireneo de

9 Copleston, F., Historia de la Filosofía (trad. J. C. García Borrón), vol. I, Ariel, Barcelona, 2011, pp. 333-335.

10 Dicho criterio es compartido por ForTIN, E. L., «Santo Tomás de Aquino (1225-1274)» (trad. L. García Urriza), en AA.VV. (Strauss, L. y Crosey, J. [comps.]), Historia de la Filosofía Política, Fondo de Cultura Económica, México, 1993, p. 252: «Hasta aquí la filosofía política parecería estar en armonía sustancial con la de Aristóteles, de la que manifiestamente se deriva. Sin embargo, un examen más minucioso revela que al adoptar el concepto aristotélico de la naturaleza política del hombre y de la vida humana, Santo Tomás de Aquino lo ha modificado profundamente bajo la influencia del cristianismo y del estoicismo, y a consecuencia del alto grado de claridad y de certidumbre que atribuye a la noción de Dios como legislador, en ambas tradiciones. La excelencia humana ya no es definida ni circunscrita por las condiciones de la vida política».

11 San Agustín, La Ciudad de Dios (trad. J. Morán), XV, V, Biblioteca de Autores Cristianos, Madrid, 1958, pp. 1002-1003, señala que el origen de la ciudad terrena está marcado por el pecado de nuestros primeros padres, en tanto que Caín fue el fundador de la ciudad terrenal y que Roma, arquetipo de Estado durante la Antigüedad, surgió de la disputa fraticida entre Rómulo y Remo. Sin embargo, Rommen, H., El Estado en el pensamiento católico (trad. E. Tierno), Instituto de Centros Políticos, Madrid, 1956, p. 264, n. 16, defiende que esta visión pesimista del Estado corresponde más a los intérpretes de San Agustín -y, especialmente, a la doctrina protestanteque al propio Obispo de Hipona, ya que éste, en su obra De Genesi ad litteram (VIII, 9, 17), consideraba necesario el gobierno político durante el estado de naturaleza anterior al pecado original. 
Lyon $^{12}$ - con el del Doctor Angélico. Para éste último, el Estado no constituye un mal necesario que se deba soportar debido a la caída de la naturaleza humana tras el pecado original, sino la consecuencia natural del carácter social y comunitario de la persona ${ }^{13}$. Por tanto no mantiene una postura radicalmente pesimista respecto al ejercicio poder político, ni tampoco predica una subordinación absoluta del poder civil al religioso, ya que cada uno tiene una esfera propia y específica a la que atender. En este sentido, el Estado es una realidad querida por Dios que está llamada a cumplir un papel insustituible consistente en la promoción del bien común de la sociedad ${ }^{14}$. Con ello, Santo Tomás se distancia del hierocratismo o la visión negativa del gobierno temporal que puede apreciarse en algunos Santos Padres.

Según CAPPELLETTI, esta divergencia tiene su origen en el muy diferente contexto histórico de ambos autores ${ }^{15}$. Mientras San Agustín se encontraba aún muy cercano a las persecuciones imperiales, con el razonable temor de que un nuevo poder instituido -dada la agonía del mundo romano- se tornase hostil contra la fe católica, Santo Tomás vive durante el esplendor de la Cristiandad medieval, cuyos únicos enemigos provenían del exterior -el Islam- o de la disidencia interior -herejía - y contra los cuales ya se contaba con la decidida colaboración del brazo secular.

Ante ambas tendencias, cabe concluir que el Aquinate mantiene un sistema propio y coherente frente las dos tradiciones que le llevará, en adecuada síntesis, a aprovechar lo mejor de cada una ${ }^{16}$. Del aristotelismo

12 Rhonheimer, M., «Perché una filosofia politica? Elementi istorici per una risposta», cit., p. 237: «San Ireneo, ya antes que San Agustín, explicaba con claridad este pensamiento político residual, afirmando que los hombres en primer lugar son pecadores y viciosos; el estado, mediante la ley, tiene la función de asegurar con el miedo del castigo que los peces grandes no se coman a los pequeños».

13 Santo Tomás De Aquino, De Regimine Principum (trad. L. Carbonero), Izquierdo, Sevilla, 1861 [1265/1267], I, 1, p. 6-8: «Siendo natural, que el hombre viva en sociedad, debe haber en ella todo cuanto sea necesario para su gobierno; porque si en una sociedad nadie se ocupara más que de sí mismo, pronto se disolvería, a no ser que hubiera uno que la detuviera en su perdición, consagrándose al régimen y dirección de los intereses comunes [...] Es, pues, necesario que en toda sociedad haya un poder directivo».

14 Sigmund, P., «Law and Politics», cit., pp. 217-218.

15 Cappelletti, A. J., «El aristotelismo político de Santo Tomás de Aquino», en Revista de Filosofía de la Universidad de Costa Rica, vol. XXV, n. ${ }^{\circ} 62$ (1987), pp. 202-203.

16 Rhonheimer, M., «Fundamental Rights, Moral Law, and the Legal Defense of Life in a Constitucional Democracy» (trad. P. Garozza), en The American fournal of furisprudence, n. ${ }^{\circ} 43$ (1998), pp. 142-143, remarca el distanciamiento de Santo Tomás, por un lado, respecto al perfeccionismo moral de la polis predicada por el aristotelismo y, del otro, en cuanto a la idea de subordinación del poder político al espiritual propia del denominado «agustinismo político» medieval. 
tomará la necesidad de promover el gobierno político como una institución indispensable y positiva para la sociabilidad humana, que debe ser empleada en provecho del bien común. Sin embargo, la tradición cristiana le proporcionará un argumento decisivo, fundado en el carácter sagrado de la persona, para evitar una absorción del individuo por el poder político bajo el pretexto de la suprema defensa -la tan traída y llevada raison d'État- del interés general.

De esta forma, adoptando esta posición de equilibrio entre las fuentes filosóficas y religiosas en las que se inspira, Santo Tomás proporcionará los cimientos para una nueva concepción del poder político que resultará decisiva en el posterior nacimiento del Estado social democrático y de derecho ${ }^{17}$.

\section{El estado de derecho en Santo Tomás de Aquino}

\subsection{El imperio de la ley}

La idea de un gobierno regido por leyes razonables, y no por la arbitrariedad o el capricho de quien ostente la supremacía política -el príncipe-, constituye un auténtico lugar común en el pensamiento del Aquinate. Valga como ejemplo uno de sus textos más conocidos:

«Pero para que el querer de la voluntad respecto de estos medios tenga el valor de ley, es necesario que esté regulado por la razón. Y en este sentido hay que entender aquello de que la voluntad del príncipe tiene fuerza de ley. De lo contrario, la voluntad del príncipe, más que ley, sería iniquidad $\gg^{18}$.

La respuesta hace referencia a la famosa máxima del Digesto I, 4, 1: $\ll$ Lo que place al príncipe tiene fuerza de ley ${ }^{19}$. Dicha expresión, entendida en su sen-

17 NovaK, M., «Si Santo Tomás estuviese vivo hoy...», Estudios Públicos, n. ${ }^{\circ} 43$ (1991), p. 181: «Sería exagerado argumentar que Aquino, antes de Montesquieu y de Madison, había predicho la forma de las instituciones [democráticas modernas] que podrían permitir la expresión rutinaria y regular de ese consentimiento. Sin embargo, Aquino validó, en efecto, la búsqueda de esas instituciones y anunció sus primeros principios».

18 Santo Tomás De Aquino, Summa Theologica, I-II, q. 90, a 1, ad. 3 (trad. J. M. Rodríguez), vol. 2, Biblioteca de Autores Católicos, Madrid, 1989, p. 705.

19 Este principio constituye una expresión propia del Derecho romano tardoimperial, donde la concentración del poder en manos del Emperador -debidamente auxiliado por sus funcionarios- resulta casi absoluta. 
tido literal, constituye un claro precedente de lo que posteriormente vendría en conocerse como el absolutismo monárquico que, unido a la doctrina del origen divino de la monarquía, serviría de soporte jurídico-doctrinal al Antiguo Régimen.

Sin embargo, Santo Tomás, sin rechazar la fórmula de forma tajante -ya que se cumple en ella uno de los requisitos básicos de la ley, cual es la promulgación por la autoridad competente- la cuestiona en tanto que carece de otro presupuesto esencial: su adecuación a la razón ${ }^{20}$. Y es que, si la norma no resulta razonable, tampoco servirá para cumplir la tercera exigencia consistente en la salvaguarda del bien común ${ }^{21}$. En este sentido, la identificación de la ley como norma jurídica se apoya en un elemento esencial: las leyes deben obedecer a la razón y no a una pura arbitrariedad o decisión caprichosa, dada la natural racionalidad humana ${ }^{22}$.

En este sentido, cuando el Aquinate utiliza la expresión «ley regulada por la razón» está señalando una cualidad fundamental para su plena legitimidad. Y ésta no es otra que la imperiosa necesidad de que el Derecho positivo responda a unas exigencias de justicia ${ }^{23}$, lo cual se conseguirá mediante un ade-

20 FAssò, G., Historia de la Filosofía del Derecho. Antiguiedad y Edad Media (trad. F. Lorca), vol. I, Pirámide, Madrid, 1982, p. 188: «... el aforismo romano en virtud del cual la voluntad del príncipe tiene fuerza de ley -aforismo que en la mayor parte de los escritores medievales, tomado a la letra, sirvió de fundamento al absolutismo político- debe ser entendido en el sentido de que se trata de una voluntad racional». Puntualizamos en este extremo al insigne jurista italiano, ya que la doctrina del poder absoluto de los reyes empezó a configurarse durante la época renacentista, y no propiamente en la medieval, como consecuencia de la acumulación de poder en manos de los reyes, paralela al detrimento de las facultades que ostentan los estamentos nobiliario y eclesial, las ciudades o las diferentes corporaciones. Como indica CONTRERAS, F. J., «Los derechos humanos como versión de la ley natural (I)», en AA.VV. (Contreras, F. J. [dir.]), El sentido de la libertad. Historia y vigencia de la ley natural, Stella Maris, Barcelona, 2014, pp. 144-145, durante los siglos XV y XVI se pasa del sistema poliárquico y asimétrico medieval a la centralización del poder en las monarquías nacionales.

21 La definición de la ley aparece en la clásica cita de SANTo Tomás DE Aquino, Summa Theologica, I-II, q. 90, a 3, c., vol. 2, cit., p. 708: «... una ordenación de la razón al bien común, promulgada por quien tiene el cuidado de la comunidad».

22 Ibid., I-II, q. 90, a. 1, c., vol. 2, cit., p. 704: «Ahora bien, la regla y medida de nuestros actos es la razón, que, como ya vimos (q. 1, a. 1, ad. 3), constituye el primer principio de los actos humanos... Síguese, pues, que la la ley es algo que pertenece a la razón».

23 Ollero, A., «Hermenéutica jurídica y ontología en Tomás de Aquino», Anuario de Estudios Sociales y furídicos, vol. III (1974), p. 295, nota 11, mantiene que el Doctor Angélico, cuando utiliza la expresión «justicia» dentro del Tratado de la ley de la Summa, no hace referencia a la virtud moral sino al mandato de ajustamiento racional de las conductas humanas, es decir, al gobierno de las mismas por el imperio de la ley y la razón. 
cuado ajustamiento de sus mandatos a la ley natural -como primera norma de la razón ${ }^{24}-$, de la que se deriva y a la cual se encuentra subordinada ${ }^{25}$.

Con este planteamiento, Santo Tomás instaura el principio de que el poder político debe someterse a unos parámetros de racionalidad, expresados en las leyes que rigen la convivencia social.

Si partimos de estas dos premisas, a saber, que las leyes positivas están subordinadas a la ley natural, expresión máxima de la cualidad racional de los seres humanos, y que el gobernante se encuentra al servicio del bien común político $^{26}$, a cuya consecución se ordenan las leyes ${ }^{27}$, resulta evidente que quien ostenta el poder temporal debe sujetarse a dichas disposiciones en el ejercicio de su autoridad, so pena de incumplir la función que le es propia.

Una consecuencia de este planteamiento tomista es su doctrina sobre la obligación en conciencia de cumplir las leyes ${ }^{28}$. Se establece como principio general el deber de acatar el poder instituido y sus disposiciones, pero, en el supuesto de que las leyes humanas resultaran injustas en un grado supremo, ello autorizaría la legítima desobediencia a sus mandatos puesto que se han corrompido hasta hacerlas irreconocibles ${ }^{29}$.

24 Santo Tomás de Aquino, Summa Theologica, I-II, q. 95, a. 2, c., vol. 2, cit., p. 742.

25 Ibid., II-II, q. 60, a. 5, ad 2., vol. 3, cit., p. 497: «Así como la ley escrita no da fuerza al derecho natural, tampoco puede disminuírsela o quitársela, puesto que la voluntad del hombre no puede cambiar la naturaleza. Por lo cual, si la ley escrita contiene algo contra el derecho natural, es injusta y no tiene fuerza para obligar... De ahí que tales escrituras no se llamen leyes, sino más bien corrupciones de la ley». El mismo criterio se adopta por LOCKE, J., Segundo Tratado sobre el Gobierno Civil (trad. C. Mellizo), Tecnos, Madrid, 2016 [1690], n. 12, p. 18: «... muchas de las leyes municipales de los diferentes países... sólo resultan justas cuando se basan en la ley de naturaleza mediante la cual deben ser reguladas e interpretadas».

26 Con independencia de la forma de gobierno que se adopte, la misma debe buscar siempre el bien común, como señala SANTo Tomás DE Aquino, Summa Theologica, I-II, q. 90, a. 3, c., vol. 2, cit., p. 706: «Pero ordenar algo al bien común corresponde, ya sea a todo el pueblo, ya a alguien que haga sus veces».

27 Santo Tomás de Aquino, Summa Theologica, I-II, q. 90, a. 2, c., vol. 2, cit., p. 705.

28 Ibid., I-II, q. 96, a. 4, c., pp. 750-751.

29 Según el Aquinate, si las leyes que fueran contrarias a los «bienes divinos» jamás deberían ser obedecidas. En la actualidad, podemos interpretar dicha expresión considerándola referida a los actos gubernativos o disposiciones legales que atenten de forma directa y gravísima contra la dignidad de la persona, es decir, violando frontal e indubitadamente los derechos humanos. En este último sentido es como debe entenderse la posición expresada, en clara sintonía con el pensamiento tomista, por RADbRUCH, G., Introducción a la Filosofía del Derecho (trad. W. Roces), Fondo de Cultura Económica, Mexico, 1974 [1948], pp. 51-52 y 180: «Así pues, si es verdad que, en la mayoría de los casos, la validez del Derecho positivo puede justificarse por las exigencias de la seguridad jurídica, no es menos cierto que, en casos excepcionales, tratándose de leyes extraordinariamente injustas, cabe también la posibilidad de desconocer la validez de tales 
Otra consecuencia de la aplicación de estos principios - diferente, aunque históricamente ligada a la anterior ${ }^{30}$ - es la exigencia de un Estado que se rija por las leyes y no por la decisión arbitraria del gobernante de turno. Al aludir a la exigencia de racionalidad legal, Santo Tomás expresa la necesidad de que se imponga el imperio de la ley sobre la voluntad de los hombres ${ }^{31}$. Como afirma FASSÒ, la teoría sobre la ley en general, contenida en las cuestiones 90 a 97 del libro I-II de la Summa Theologica, implica un embrionario Estado de derecho que se rige por la razón y la utilidad común de los miembros de la sociedad ${ }^{32}$.

La forma política denominada «constitucionalismo moderno», uno de cuyos elementos fundamentales es la existencia de un poder político sujeto a las premisas de la ley, tiene su origen más próximo en el rule of law instaurado en Gran Bretaña desde el siglo XVII y, de forma más remota, en la teorías medievales de las que se hizo eco el pensamiento tomista sobre la racionalidad de la ley y la limitación del poder del príncipe a través de la figura de un régimen mixto ${ }^{33}$, concepto éste último que tendremos ocasión de examinar más adelante.

leyes, por razón de su injusticia [...] Por donde vemos cómo, a la vuelta de un siglo de positivismo jurídico, resucita aquella idea de un derecho superior a la ley, supralegal, aquel rasero con el que medir las mismas leyes positivas y considerarlas como actos contrarios a Derecho, como desafueros bajo forma legal».

30 No debemos olvidar que la instauración de una de las primeras manifestaciones del Estado de Derecho, en el sentido moderno de la palabra, surgió como respuesta al opresivo poder británico sobre sus colonias norteamericanas, lo cual justificaba la sublevación frente al gobierno constituido. Al respecto, son extraordinariamente significativas las afirmaciones contenidas en la Declaración de Independencia de los Estados Unidos: «... que cuando quiera que una forma de gobierno se haga destructora de estos principios [la igualdad entre los hombres, la tutela de sus derechos inalienables por el gobierno constituido y el consentimiento de los ciudadanos como base del poder político], el pueblo tiene el derecho a reformarla o abolirla e instituir un nuevo gobierno que se funde en dichos principios». En dicho texto resulta evidente la influencia de LocKe, J., Segundo Tratado sobre el Gobierno Civil, cit., n. 222, p. 212: «Siempre que los legisladores tratan de arrebatar y destruir la propiedad del pueblo, o intentan reducir el pueblo a la esclavitud bajo un poder arbitrario... queda absuelto de obediencia... Por lo tanto, siempre que el poder legislativo viole esta ley fundamental de la sociedad..., estará devolviendo al pueblo el poder que éste le dio, y el pueblo tendrá entonces el derecho de retomar su libertad original y de establecer un nuevo cuerpo legislativo que le parezca apropiado».

31 FINNIS, J., Ley Natural y Derechos Naturales (trad. C. Orrego), Abeledo-Perrot, Buenos Aires, 2000, p. 300.

32 FASsò, G., La legge della raggione, Il Mulino, Bolonia, 1966, pp. 83-84.

33 Rhonheimer, M., Cristianismo y laicidad. Historia y actualidad de una relación compleja (trad. J. R. Pérez Arangüena), Rialp, Madrid, 2009, pp. 73-75. 
Como expresión de esta primacía de la ley, resulta asimismo evidente la preferencia del santo dominico por las disposiciones legales frente a lo que podríamos entender como «decisionismo judicial».

Santo Tomás, siguiendo el precedente aristotélico ${ }^{34}$, entendía que la abstracción propia de las leyes, una mayor serenidad en su elaboración y la elección de un selecto grupo de personas para su redacción, les dotaba de neta superioridad frente a sentencias que no siempre se dictarían por jueces lo suficientemente capaces, objetivos y ecuánimes ${ }^{35}$.

En este sentido, resulta imprescindible dejar al ámbito de la ley el mayor espacio posible, restringiendo la esfera judicial exclusivamente a la comprobación de la veracidad o no de los hechos alegados por las partes ${ }^{36}$.

Sin embargo, no es menos cierto que el Aquinate, en otros pasajes, concede a las sentencias dictadas por los jueces el valor de leyes aplicadas al caso concreto como producto de una continua y compleja labor de determinación, tendente a la consecución lo justo ${ }^{37}$. Pero incluso, en este supuesto, se entiende que el juez no crea para sí un ámbito de arbitrariedad, semejante al que podría generar el déspota o un monarca tirano, sino que también queda sujeto a la ley como expresión de suprema racionalidad ${ }^{38}$.

34 Aristóteles, Política (trad. C. García y A. Pérez), Alianza Editorial, Madrid, 2014, III, 11, p. 167: «... deben ser soberanas las leyes bien establecidas, ya que el magistrado, ya sea uno o sean varios, deben tener poder sólo en lo que las leyes no puedan indicar con precisión» y IV, 2 , p. 202: «... es preciso que la ley gobierne todo [en líneas generales], aunque los aspectos concretos, [se dejen a] los magistrados...».

35 SAnto Tomás De Aquino, Summa Theologica, I-II, q. 95, a. 1, ad. 2, vol. 2, cit., p. 741.

36 En principio, podría pensarse que esta posición es idéntica a la mantenida por los revolucionarios franceses, basándose en la expresión de MonTESQuieu, El Espiritu de las Leyes (trad. S. García del Mazo), Librería General de Victoriano Suárez, Madrid, 1906 [1748], p. 237: «Ahora bien, los jueces de la nación no son... sino la boca por donde habla la ley, seres inanimados que no pueden moderar la fuerza ni el rigor de las leyes». Sin embargo, la coincidencia es sólo aparente. El aforismo reproducido manifiesta el interés político en controlar a los miembros de la judicatura al considerarlos como vestigios del Antiguo Régimen. Por su parte, el planteamiento tomista es diferente puesto que no obedece a una situación coyuntural de lucha por el poder, sino al deseo de crear un sistema racional que facilite la consecución del bien común.

37 Santo Tomás De Aquino, Summa Theologica, I-II, q. 99, a. 5, ad. 2 (trad. J. M. Rodríguez y L. Jiménez), vol. 2, cit., p. 790: «Juicio significa ejecución de justicia, la cual consiste en la aplicación precisa de la razón a casos particulares... Por esto, a veces, bajo el nombre de juicios se comprenden los preceptos judiciales y morales...» y II-II, q. 67, a. 1, c., vol. 3, cit., p. 552: «La sentencia del juez tiene cierto carácter de ley particular dictada respecto a un hecho particular...».

38 Ollero, A., «Hermenéutica jurídica y ontología en Tomás de Aquino», cit., p. 299, n. 20: «Pero, sin duda, lo que Tomás propone no es un movimiento de 'derecho libre' en el que el juez sería soberano absoluto, ya que su función no se entiende sin referencia a la ley». 
Como corolario de lo expuesto, resulta evidente que la idea de un Estado regido por el imperio de leyes racionales, y no por el capricho del gobernante, constituye un elemento propio de la doctrina tomista que, si bien no fue plenamente original al hundir sus raíces en el pensamiento de Aristóteles ${ }^{39}$, sí contribuyó a remozarla y, sobre todo, a servir de eslabón entre el pensamiento clásico y el liberalismo moderno que hizo suyo dicho principio para plasmarlo en las revoluciones de fines del siglo XVIII ${ }^{40}$. Buena prueba de ello es la estrecha conexión que se puede encontrar entre la calificación por el Aquinate como injustas de aquellas leyes dictadas por un príncipe para su propio provecho y obviando el bien común ${ }^{41}$-las cuales, por tanto, no obligarían en conciencia a los súbditos ${ }^{42}-$ y la definición del ejercicio tiránico del poder por Locke como el «uso de del poder que se tiene, no para el bien de quienes están bajo ese poder, sino para propia ventaja de quien lo ostenta... [para] satisfacer su propia ambición, venganza, avaricia o cualquier otra pasión irregular ${ }^{43}$.

\subsection{La división de poderes}

Como es bien sabido, la doctrina de la división de poderes, enunciada por Locke y posteriormente popularizada por Montesquieu ${ }^{44}$, constituye un elemento esencial del Estado de Derecho. Según la misma, el poder no debe concentrarse en una misma persona o institución sino dividirse en tres instancias diferentes que se limitan entre sí: la legislativa, la ejecutiva y la judicial.

39 Aristóteles, Política, cit., IV, 4, p. 202: «Porque donde no gobiernan las leyes no hay sistema...».

40 Fassò, G., La legge della raggione, cit., pp. 84-85 y Copleston, F., Historia de la Filosofía (trad. A. Domènech), vol. 2, tomo 5, Ariel, Barcelona, 2011, p. 112, consideran que la doctrina del Aquinate es un precedente de la filosofía política de Locke, el padre del liberalismo, acerca del poder político y sus límites.

41 Santo Tomás de Aquino, Summa Theologica, I-II, q. 96, a. 4, c., vol.2, cit., p. 751.

42 Ibid., I-II, q. 96, a. 4, ad. 3, vol.2, cit., p. 751 y II-II, q. 104, a. 6, ad. 3, vol. 4, cit., pp. 218-219.

43 Locke, J., Segundo Tratado sobre el Gobierno Civil, cit., n. 199, p. 193.

44 Ibid., n. 143-148, pp. 143-146 y MONTESQUIEU, El Espiritu de las Leyes, cit., pp. 227-228. La principal discrepancia entre ambos autores es que el británico considera que la judicatura se integra en el ejecutivo y, además, crea el poder federativo, entendido como aquél a quien corresponde autorizar las declaraciones de guerra, los tratados de paz y todo lo concerniente a lo que hoy denominaríamos «asuntos exteriores», si bien reconoce que en la mayoría de los casos su titular coincidirá con quien ostenta el poder ejecutivo. 
El Doctor Angélico se manifiesta claramente a favor de esta separación de poderes y de la limitación entre las diversas instancias de decisión.

Santo Tomás, al establecer su opinión acerca del sistema ideal ${ }^{45}$, considera imprescindible un régimen mixto en el cual se coordinen, de forma adecuada, la dirección del gobierno por una sola persona -monarquía-, su asesoramiento por consejeros especialmente aptos y cualificados para tal fin -aristocracia representativa y meritocrática- y la intervención de todo el pueblo en la elección de dichas magistraturas -democracia- ${ }^{46}$. De esta forma consigue la concurrencia una pluralidad de personas y grupos implicados, si bien en diferente grado, respecto a la gestión de la res publica.

Dicha solución se defiende, principalmente, por entenderse que una adecuada cooperación de todos los miembros del cuerpo social constituye la mejor fórmula para un régimen que persiga el bien común. En efecto, con ello se consigue que nadie se considere ajeno o desplazado por esta forma de ejercer el poder ${ }^{47}$. Asimismo, para evitar una excesiva dispersión de la capacidad decisoria del gobierno que fomente la anarquía y el desorden, se compensa dicho elemento participativo con la concentración del poder ejecutivo en una sola persona ${ }^{48}$.

Este modelo, que es el que mejor garantiza la concordia y la paz social indispensables para un desarrollo adecuado de la convivencia, no se aparta,

45 Santo Tomás De Aquino, Summa Theologica, I-II, q. 95, a. 4, c., cit., p. 745: «Y existe finalmente, otro [sistema político], constituido por la combinación de los anteriores [monarquía, aristrocacia y democracia], que es el mejor».

$46 \mathrm{Ibid}$., I-II, q. 105, a. 1, c., cit., p. 864: «Tal es la buena constitución política, en la que se juntan la monarquía -por cuanto es uno el que preside a toda la nación-, la aristocracia -porque son muchos los que participan en el ejercicio del poder-y la democracia, que es el poder del pueblo, por cuanto estos que ejercen el poder pueden ser elegidos del pueblo y es el pueblo quien los elige». Como un ejemplo más de la espléndida síntesis tomista, se mencionan como fuentes de este régimen mixto la obra de Aristóteles -Política- y el Antiguo Testamento -concretamente, los libros del Éxodo y Deutoronomio-.

$47 \mathrm{Ibid}$., I-II, q. 105, a. 1, c., cit., p. 864: «La mejor constitución en una ciudad o nación es aquella en que uno es el depositario del poder y tiene la presidencia sobre todos, de tal suerte que algunos participen de ese poder y, sin embargo, ese poder sea de todos, en cuanto que todos pueden ser elegidos y todos toman parte en la elección».

48 FinNIS, J., Ley Natural y Derechos Naturales, cit., p. 280: «La preferencia clásica por el gobierno de uno -'mon-arquía'- no era una preferencia por los cargos vitalicios, títulos hereditarios, o las parafernalias de las cortes reales, sino que expresaba una preocupación por la efectividad de la coordinación, por la unidad y en consecuencia la efectividad en la búsqueda del bien común». 
grosso modo, de la esencia del Estado constitucional democrático tal y como actualmente se encuentra configurado ${ }^{49}$.

También es cierto que, si se consultan otros textos de Santo Tomás, parece que en los mismos opta por una solución diferente, considerando la instauración de la monarquía como sistema político ideal ${ }^{50}$. No obstante, debe entenderse que el régimen mixto constituye el arquetipo del pensamiento político tomista por las siguientes razones:

- La opción en favor de la monarquía se recoge, principalmente, en $D e$ Regimine Principum, escrito por encargo del Rey de Chipre ${ }^{51}$. Atendiendo al cargo del destinatario, parece lógico que esta obra sea decididamente laudatoria del papel de los reyes en el gobierno de la ciudad terrena. Esto también estaría ligado a la función de dicho libro como modelo de conducta dirigido a los gobernantes ${ }^{52}$.

- Conviene separar en las obras del Aquinate lo que él entiende como un sistema óptimo, dentro de un plano ideal, del que resultaría mejor atendiendo a la imperfecta realidad $\operatorname{social}^{53}$. Si bien la monarquía se presentaría como lo más adecuado dentro de una sociedad de personas virtuosas y buscadoras de la verdad, el régimen mixto responde de una forma más práctica a la necesidad de defender el bien común atendiendo a la debilidad de la condición humana.

49 A juicio de Rhonheimer, M. The Common Good of Constitucional Democracy, Catholic University of America Press, Baltimore, 2013, pp. 25-26, n. 55, el moderno Estado constitucional democrático constituye la más acabada expresión histórica del régimen mixto previsto en la Summa.

50 Santo Tomás de Aquino, De Regimine Principum, I, 2, cit., pp. 12-16.

51 En la época en que se redactó esta obra, el reino chipriota se encontraba sujeto a múltiples revueltas y sediciones, lo cual justificaba la necesidad de defender un reforzamiento de la autoridad del monarca, vid. Vitoria, F. (edición crítica de Cordero, J.), Relectio de Potestae Civili. Estudios sobre su Filosofía Política, Consejo Superior de Investigaciones Científicas, Madrid, 2008, p. 404, nota 11.

52 Santo Tomás de Aquino, De Regimine Principum I, Argumento, cit., pp. 1-2: «... me ha parecido lo mejor, escribir un libro sobre el gobierno monárquico, en el que expusiera con la mayor diligencia el origen de la Monarquía y cuanto se refiere al ejercicio de la autoridad real, con arreglo al testimonio de la Sagrada Escritura, a los principios de la filosofía y a los ejemplos de los reyes más esclarecidos».

53 Ibid., I, 3, cit., p. 17: «... la monarquía es contraria a la tiranía, aunque en ambas esté el poder en manos de uno solo. Ya hemos probado que el gobierno monárquico es el mejor; luego si lo que es mejor es contrario a lo que es peor, se sigue necesariamente que la tiranía es el peor de los gobiernos». De esta forma, se pone de manifiesto el peligro evidente de que la concentración del poder propia de la monarquía pueda degenerar, si el rey abusa de su autoridad, en un régimen despótico. 
- En última instancia, cabe compatibilizar las afirmaciones, en principio contradictorias, de Santo Tomás. La solución consiste en entender que el régimen mixto constituye una variante -la más perfecta- de la monarquía o reino (regnum) $)^{54}$.

- Finalmente, no se debe interpretar el pensamiento tomista prescindiendo de su contexto histórico. Durante el siglo XIII la forma de gobierno dominante en la Cristiandad era la monarquía. Sin embargo, dicho régimen no se entendía por el Aquinate como un poder absoluto, sino limitado por la autoridad moral de la Iglesia, fuente última de legitimidad, así como por los imprescindibles pactos con el estamento nobiliario, los gremios corporativos y -especialmente en el norte de Italia- la pujante burguesía de las ciudades.

Buena prueba de esta originaria concepción de la división de poderes está en la distinción, que ya hemos anticipado, entre quien desempeña las tareas de gobernar y dirigir la sociedad hacia el bien común -un poder ejecutivo que reside en el monarca, debidamente asistido de sus consejeros ${ }^{55}-$, el que promulga las leyes -un poder legislativo que puede corresponder al pueblo o a su representante ${ }^{56}$ - y quienes dispensan justicia en los casos concretos -el poder judicial atribuido a los jueces ${ }^{57}-$.

Sin embargo, este sistema de equilibrio institucional parece quebrar en un elemento esencial: el príncipe no se encuentra vinculado coactivamente por la misma ley que él ha dictado ${ }^{58}$. La transposición directa de este razona-

54 Finnis, J., Aquinas. Moral, Political and Legal Theory, cit., p. 262, y ReCASÉNs, L., Historia de las doctrinas sobre el contrato social, Universidad Nacional Autónoma de México, México, 2003 [1941], p. 7. «Santo Tomás... reputa preferible, por meras razones de conveniencia, la monarquía limitada, esto es, un régimen mixto en el cual el poder regio se halle ligado en parte a la cooperación de otros órganos».

55 Santo Tomás de Aquino, Summa Theologica, I-II, q. 105, a. 1, c., vol. 2, cit., p. 864.

56 Ibid., I-II, q. 90, a.3, ad, 2, vol. 2, cit., p. 707: «Luego sólo el pueblo o su mandatario pueden legislar».

57 Ibid., I-II, q. 95, a.2, ad. 4, vol. 2, cit., p. 743: «Tales determinaciones [particulares de la ley natural] son asumidas por los jueces expertos y prudentes a guisa de principios, a cuya luz ven rápidamente lo que se ha de juzgar como mejor en cada caso particular».

58 Santo Tomás De Aquino, Summa Theologica, I-II, q. 96, a.5, ad. 3, vol. 2, cit., pp. 752-753: «Se entiende que el príncipe está eximido de la ley en cuanto al poder coactivo de la misma, pues la ley no tiene fuerza coactiva más que por la autoridad del príncipe, y nadie puede coaccionarse a sí mismo. Se dice, pues, que el príncipe está exento de la ley, porque nadie puede pronunciar contra él un juicio condenatorio en caso de que falte a la ley... el príncipe no está exento de la ley en cuanto al poder directivo de la misma, aunque ha de cumplirla voluntariamente y no por coacción». 
miento a la situación contemporánea implicaría la inexistencia de un efectivo control jurisdiccional sobre el poder ejecutivo.

Para entender esta afirmación del Aquinate, contextualizándola adecuadamente en su época, resulta imprescindible tener en cuenta los siguientes extremos:

- La doctrina contenida en la Summa precede en cuatro siglos a la aparición de las modernas concepciones sobre la división de poderes, razón por la cual resulta evidente que en esta primera aproximación a la figura existan aristas que deberán ser posteriormente corregidas gracias a una mayor experiencia histórica.

- A pesar de todo, el poder del príncipe dista mucho de entenderse como arbitrario o ilimitado por el Doctor Angélico. El gobernante continúa sujeto al imperativo de la ley en virtud de su poder directivo, es decir, como regla moral ineludible que le obliga de la misma forma que a cualquier otro integrante de la sociedad. Será la secularización del poder político, muy posterior a Santo Tomás, la que demostrará que la forma más eficaz para limitar el ejercicio abusivo de un poder temporal no es la exhortación a principios religiosos y morales $^{59}$, sino la existencia de otro poder terreno que lo contrapese y reequilibre ${ }^{60}$.

Por tanto, Santo Tomás también se adelantó a su tiempo al considerar la necesidad de que el poder se dividiera en diversas instancias que funcionaban de forma independiente y sujetas a límites. A pesar de ello, en su doctrina política aún se observan reminiscencias del pensamiento medieval como lo demuestra el hecho de no admitir un control judicial -y, por tanto, jurídicamente efectivo- que limite las atribuciones propias del monarca. Serán los discípulos del Aquinate quienes darán el decisivo paso de considerar que el rey está vinculado jurídicamente al cumplimiento de las leyes ${ }^{61}$.

59 Como indican Contreras, F. J., «Los derechos humanos como versión de la ley natural (I)», en AA.VV. (Contreras, F. J. [dir.]), El sentido de la libertad. Historia y vigencia de la ley natural, cit., pp. 143-144; y BobBIo, N., El tiempo de los derechos, cit., p. 41, hasta el siglo XVII no se tuvo en cuenta que los deberes del monarca implicaban recíprocos derechos en favor de los ciudadanos. En este sentido, se mantiene una visión paternalista del poder de los monarcas, que sólo están obligados a responder de sus actos ante Dios y su conciencia y no ante el pueblo.

60 Rhonheimer, M., Cristianismo y laicidad. Historia y actualidad de una relación compleja, cit., pp. 63 y 75 .

61 Incluso seguidores fidelísimos de Santo Tomás difieren de él en este punto, como sucede con Vitoria, F. (edición crítica de Cordero, J.), Relectio de Potestae Civili. Estudios sobre su Filosofía Politica, cit., n. 21, pp. 61-62, cuando defiende que las leyes civiles obligan a legisladores y reyes 


\subsection{Derechos bumanos}

Otra cuestión que ha suscitado amplios debates es si el Aquinate, especialmente en su obra Summa Theologica, defiende la existencia de derechos humanos o, utilizando otro lenguaje más cercano a su época, de derechos naturales del individuo. $\mathrm{Al}$ respecto pueden distinguirse las siguientes posturas $^{62}$ :

a) Tesis negacionista

Se funda, principalmente, en que el Doctor Angélico no utiliza en su obra la expresión «derechos naturales del hombre» u otra similar. Ello se debe, según VILLEY, a que el nacimiento del concepto de derecho subjetivo, base jurídica de los derechos humanos, surgió el mundo jurídico un siglo después, de la mano del franciscano Guillermo de Ockham en su Opus Nonagenta Dierum ${ }^{63}$.

Asimismo, MACINTYRE afirma que resulta absurdo buscar en la producción filosófica del Aquinate cualquier mención de derechos humanos, en tanto que la misma constituye un artificio ${ }^{64}$, creado por el pensamiento moderno, que no guarda relación alguna con la doctrina clásica sino más bien se contrapone a ella. Y es que, utilizando los mismos términos que el filósofo escocés, las divergencias entre el pensamiento clásico y el ilustrado, en torno a lo que es la justicia y el derecho, son «inconmensurables» entre sí 65 .

Para ambos autores, la concepción del derecho para Santo Tomás, entendida como una relación de medida o equilibrio entre personas -la cosa justa o

basándose en tres argumentos: si el legislador no observa sus propias leyes no podrá exigir su cumplimiento a los demás ciudadanos; las leyes del rey obligan a todos del mismo modo que las aprobadas por toda la comunidad política (república) y, por último, el precedente histórico de los senatus consulta romanos, vinculantes para los senadores que los aprobaban, y de los plebiscitos respecto a los miembros de la propia plebe.

62 Un análisis bastante completo, acerca de las diferentes pronunciamientos doctrinales sobre la cuestión, puede consultarse en MASSINI-CORREAS, C. I., «Realismo y derechos humanos: una cuestión controvertida», Revista Universitaria de Mendoza, n 6/7, Mendoza, 1987-1988, <http:// www.um.edu.ar/ojs-new/index.php/RUM/article/view/159/181> [consulta: 19-03-2017].

63 Villey, M., Seize essais de Philosophie du Droit dont un sur la crise universitaire, Dalloz, Paris, 1969, pp. $140-142$ y $158-178$.

64 Macintyre, A., Tras la virtud (trad. A. Valcárcel), Crítica, Barcelona, 2004, p. 98: «... la verdad es sencilla: no existen tales derechos [humanos o naturales] y creer en ello es como afirmar que creemos en brujas y unicornios».

65 MacintYRe, A., Tres versiones rivales de la ética (trad. R. Rovira), Rialp, Madrid, 1992. 
ajustada ${ }^{66}$, resulta incompatible con la consideración del mismo como poder de disposición o facultad del individuo dejada a su libre albedrío ${ }^{67}$. Por ello, resultaría un auténtico abuso considerar al Aquinate como un precursor de los derechos del hombre propios de la Modernidad. Sin embargo, otros autores defienden que el derecho subjetivo no tiene una raíz esencialmente individualista, sino que respondió a la necesidad de regular, mediante nuevas fórmulas de justicia, el naciente marco de relaciones sociales surgidas durante la Europa bajomedieval ${ }^{68}$.

b) Tesis afirmativa

FINNIS, rectificando su anterior postura sobre la cuestión ${ }^{69}$, entiende que pueden encontrarse rastros de la doctrina de los derechos humanos en la obra del Aquinate. En este sentido, si bien es cierto que en ningún caso utiliza el término «derechos del hombre» en el sentido moderno, no lo es menos que el Doctor Angélico tenía claro el concepto ${ }^{70}$. Se trataría, pues, de un reconocimiento implícito de dicha figura.

La afirmación del catedrático australiano se basa en una lectura a sensu contrario de los textos de la Summa Theologica en los que se hace referencia a los actos injustos -iniuriae- que privan a las personas de sus legítimos bienes ${ }^{71}$. Precisamente en el reverso de dichas injusticias puede identificarse el derecho de los individuos a que se respeten sus bienes fundamentales: vida, propiedad, presunción de inocencia u honor y buena fama ${ }^{72}$. Es, pues, en dicho sentido

66 Santo Tomás de Aquino, Summa Theologica, II-II, q. 57, aa. 1 y 2, cit., vol. 3, pp. 470-471.

67 Villey, M., Seize essais de Philosophie du Droit dont un sur la crise universitaire, cit., pp. 148-149 y Macintyre, A., Tres versiones rivales de la ética, cit., pp. 108-109, calificando éste último como ilusorio y «quijotesco» el intento de Maritain de encontrar una síntesis entre tomismo y derechos humanos.

68 Tierney, B., L'idea dei diritti naturali. Diritti naturali, legge naturale e diritto canonico (1150-1625) (trad. V. Ottonelli), Il Mulino, Bolonia, 2002, p. 108.

69 FINNIS, J., Ley Natural y Derechos Naturales, cit., pp. 235-236, mantiene que el concepto de derecho, como poder o facultad del sujeto, surgió con posterioridad al Aquinate y no aparece en su pensamiento.

70 Finnis, J., Aquinas. Moral, Political and Legal Theory, cit., pp.136-137. A una conclusión similar llega Kalinowsky, G., «Le droit à la vie chez Tomas d'Aquin», Archives de Philosophie du Droit, $\mathrm{n}^{\circ} 30$ (1985), pp. 315-316, afirmando que la concepción realista de los derechos humanos que sostenía Aquino - concretamente del derecho a la vida- es más amplia que la actual, teniendo en cuanta la legalización del aborto y la eutanasia en la mayoría de los países occidentales.

71 Santo Tomás de Aquino, Summa Theologica, II-II, q. 122, a. 6, ad. 2, cit., vol. 4, pp. 302.

72 Resulta muy llamativa la coincidencia entre estos bienes fundamentales citados por el Aquinate y los derechos naturales que deben ser tutelados por el Estado, como fin originario y principal de su tarea, según Locke, J., Segundo Tratado sobre el Gobierno Civil, cit., nn. 123 y 124, p. 124: 
en el que puede considerarse que Santo Tomás contiene una tácita admisión de tales derechos, los cuales se desarrollarían más adelante en dos nuevas vertientes: formalmente, utilizando el modelo de los derechos subjetivos, y políticamente, atribuyéndoles un valor legitimador del poder constituido. Sin embargo, ORREGO ha realizado una interesante crítica a esta tesis ${ }^{73}$. A juicio del profesor chileno, la teoría del concepto implícito de derechos humanos en la Summa tiene más de reelaboración a posteriori del pensamiento tomista que de lectura fiel y reposada de los textos originales.

En efecto, parece que Finnis pretende reinterpretar las obras del Aquinate con las «gafas» de nuestra época, atribuyendo al santo dominico conceptos que, en el fondo, no aparece en sus obras. Y compartimos esta apreciación, principalmente, porque la idea de derecho que se maneja en la Summa es la propia de Cicerón y la doctrina romana clásica -el derecho como ajustamiento en clave de igualdad de relaciones entre los miembros de una sociedad- $\mathrm{y}$ dicha visión se encuentra aún bastante alejada de la que dio lugar a la actual concepción de los derechos humanos como derechos subjetivos de carácter universal ${ }^{74}$.

c) Tesis intermedia

Probablemente, la visión más acertada de la posición de Santo Tomás, en relación con un producto típico de la Modernidad como los derechos humanos, no deba referirse tanto a si hubo o no referencias explícitas o implícitas a

«... no sin razón [todo individuo] está deseoso de unirse en sociedad con otros... con el fin de preservar sus vidas, sus libertades y sus posesiones, es decir, todo eso a lo que doy el nombre genérico de propiedad [...] Por consiguiente, el grande y principal fin que lleva a los hombres a unirse en Estados... es la preservación de la propiedad».

73 OrRego, C., «La gramática de los derechos y el concepto de derechos humanos en John Finnis», Persona y Derecho, no 59 (2008), p. 154: «... la tesis de John Finnis sobre la existencia del concepto de derechos humanos en Tomás de Aquino también exige una interpretación matizada. De lo contrario, corremos el riesgo de atribuir al Aquinate pensamientos que no pasaron por su mente. Arribaríamos a la curiosa situación de reconocer que santo Tomás no babló de derechos humanos, pero sí pensó en ellos con el grado de diferenciación conceptual con que nosotros los pensamos ahora. La hipótesis de un pensamiento oculto, que jamás se expresa en toda la vida de un autor, y que, no obstante, constituye una pieza fundamental de su explicación sobre el derecho, desafía toda imaginación y toda sana hermenéutica».

74 Martínez Barrera, J. «Santo Tomás de Aquino y la Teoría de la Justicia», Derecho y Humanidades, n. ${ }^{\circ} 12$ (2006), p. 113, puntualiza que, si bien es cierto que se pueden rastrear algunos indicios de derecho subjetivo como potestad de actuar en la Summa -así lo sostuvo H. Hering en su artículo «De iure subjective sumpto apud sanctum Thomas», publicado en 1939, aportando hasta catorce citas-, lo decisivo es que el concepto básico y primario de ius que utliza el Aquinate es el derecho como cosa justa. 
los mismos en su obra sino en cómo su legado filosófico contribuyó a la eclosión de esta nueva figura jurídica durante la Modernidad.

$\mathrm{Y}$ es que los derechos del hombre, que los ilustrados defendieron en el campo de la filosofía y los pensadores liberales llevaron a la práctica política, no pueden explicarse históricamente si no se tiene en cuenta el extraordinario valor que el cristianismo otorgó a la dignidad de toda persona con independencia de su condición social.

Dentro de esta línea de pensamiento se incluye el Aquinate, algunas de cuyas aportaciones constituyen un material valioso para la posterior elaboración de los derechos del hombre como categoría jurídico-constitucional ${ }^{75}$. Pasamos a enumerar sus principales contribuciones:

- La afirmación de que la persona, como imagen de la divinidad ${ }^{76}$, goza de una especial preeminencia ontológica que debe ser objeto del máximo respeto y cuidado. Ésta es la fundamentación más radical de sus derechos inalienables, dado que utiliza una argumentación trascendente que excede del ámbito de lo temporal y lo convencional ${ }^{77}$.

- Como consecuencia de lo anterior, el ser humano no puede ser absorbido por el poder político como la simple partícula de un todo omnicomprensivo, puesto que constituye un todo en sí mismo con fines propios y una dignidad que trasciende la realidad temporal ${ }^{78}$. De esta forma se prefigura la necesidad de que el Estado actúe al servicio de sus ciudadanos y no a la inversa.

75 Un estudio muy completo acerca de la doctrina del Doctor Angélico, en relación sobre la dignidad de la persona, se ha realizado por CARPINTERO, F., «La dignidad humana en Tomás de Aquino», Persona y Derecho, n. ${ }^{\circ} 74$ (2016), pp. 97-116. No obstante, dicho autor insiste en que los derechos humanos universales, tal y como los entendemos actualmente, no existían en el siglo XIII.

76 Santo Tomás de Aquino, Summa Theologica, I, q. 29, a.3, ad.2, cit., vol. 1, p. 327: «Como quiera que subsistir en la naturaleza racional es de la máxima dignidad, todo individuo de naturaleza racional es llamado persona» y I, q. 72, ad. 3, cit., vol. 1, p. 655: «También puede decirse que los animales y las plantas son producidos en su género y en su especie, como muy alejados de la semejanza divina. En cambio, del hombre se dice que fue hecho a imagen y semejanza de Dios».

77 Contreras, F. J., «Los derechos humanos como versión de la ley natural (I)», en AA.VV. (CoNTRERAS, F. J. [dir.]), El sentido de la libertad. Historia y vigencia de la ley natural, cit., pp. 270-276 y 296-298, pone de manifiesto el gravísimo déficit de argumentación que surge cuando se pretende fundamentar los derechos humanos prescindiendo del factor religioso o trascendente.

78 SANTo Tomás De Aquino, Summa Theologica, I-II, q. 21, a. 4, ad. 3, cit., vol. 2, p. 215: «El hombre no se ordena a la comunidad política con todo su ser y con todas sus cosas... Sin embargo, todo lo que el hombre es y todo lo que puede y tiene ha de ser ordenado a Dios». 
- La formulación de la ley natural, como elemento crítico a cuyo juicio que debe ser sometido la ley positiva, implica la existencia de una frontera infranqueable para el poder político ${ }^{79}$. Si el príncipe vulnera estos límites queda deslegitimado en el ejercicio de su cargo, quedando autorizado el cambio de régimen en determinados supuestos ${ }^{80}$.

Por tanto, si bien es cierto que el Doctor Angélico no expresó los derechos humanos en su doctrina tal y como lo entendemos en la actualidad, no lo es menos que su contribución resultó decisiva para su posterior formulación. Buena prueba de ello es que los miembros de la Escuela española del Derecho natural, apoyándose en los textos del Aquinate, fueron firmes defensores, durante los siglos XVI y XVII, de la existencia de unos derechos naturales comunes a toda la familia humana ${ }^{81}$.

\section{Santo Tomás de Aquino y la Democracia}

\subsection{Papel del pueblo en el gobierno}

Santo Tomás tuvo ocasión de pronunciarse acerca de la función que debía desempeñar los componentes de la sociedad en la dirección de la res publica.

79 López, M., «Los derechos humanos: ¿límites a la soberanía?», Scio, n. ${ }^{\circ} 4$ (2009), pp. 95-96: «Al mismo tiempo, y siguiendo de nuevo al Aquinate... La ley natural es tal en tanto que está participada en las criaturas, y es eterna en tanto que está en Dios. La naturaleza, por lo tanto (por ejemplo, el ser de la persona humana), es un límite para el soberano [...] no es sólo la posición de Santo Tomás: es la de todo el cristianismo medieval [...] La soberanía está siempre limitada en el mundo cristiano... Dios y la naturaleza humana por él creada constituyen una instancia de juicio externa desde la que se juzgan las decisiones de los soberanos, y puede llevar a que sea legítimo incumplir sus mandatos»

80 Sobre la posibilidad, bajo ciertas condiciones, de cambiar el régimen vigente, vid. SANTO TOMÁs DE Aquino, De Regimine Principum, I, 6, cit., p. 36.

81 PÉrez Luño, A. E., La Filosofía del Derecho en perspectiva histórica, cit., Sevilla, 2009, p. 78 y 86: «En el trabajo primordial para la comprensión de la postura lascasiana sobre la libertad, el Tratado De regia potestate, se remite a la autoridad de Tomás de Aquino para manifestar la libertad originaria de todo ser humano [...] Las notas definitorias del alcance y significación del derecho natural a la libertad son precisadas por Las Casas con nitidez. Se trata de un derecho originario, universal, necesario e igual para todos los hombres [...] Puede, por tanto, afirmarse que el proceso de formación histórica de los derechos humanos tuvo en la doctrina de los iusnaturalistas clásicos españoles un eslabón imprescindible» y BEUCHOT, M., Filosofía y derechos Humanos, Siglo XXI, México, 2004, p. 49: «Sin embargo, en todo momento aclaramos que, en contra de la opinión común y trillada, no fue ese humanismo renacentista el único (ni el más importante, sino la antropología filosófica tomista) que los condujo [a los teólogos juristas españoles de los siglos XVI y XVII] a esa defensa de los derechos humanos». 
En primer término, el Doctor Angélico admite que la facultad de legislar se atribuya a toda la comunidad, haciéndolo compatible con que la misma se lleve a cabo también por quienes asuman su representación ${ }^{82}$. Por otro lado, se contempla -al menos como una posibilidad más dentro de las diversas configuraciones del régimen político- que sea la misma sociedad quien ostente la potestad de designar a un rey como su gobernante supremo ${ }^{83}$. Finalmente, incluso se reconoce que las normas emanadas del pueblo puedan alcanzar una autoridad superior a las que procedan del príncipe o monarca que lo rige ${ }^{84}$.

Otro argumento tomista en favor de la democracia puede localizarse en la configuración del régimen mixto como sistema idea ${ }^{85}$. En efecto, se requiere la existencia de un componente democrático, según el cual todos los miembros de la sociedad participan en la elección del príncipe y de los consejeros $y$, a su vez, pueden ser elegidos. Nos encontraríamos, pues, ante un prefiguración del actual derecho de sufragio universal activo y pasivo. Con ello se pretende atender al bien común de la forma más eficaz posible, es decir, mediante la implicación de toda la comunidad en la elección de los gobernantes ${ }^{86}$.

Como se puede apreciar en los textos examinados, la posición del Aquinate dista mucho de las teorías absolutistas sobre el inmediato origen divino de la monarquía y se acerca más a la figura de los gobiernos electivos. Partiendo de esta idea, MARITAIN expresó la necesidad de configurar el papel del gobernante como un «vicario de la multitud» que ostenta la representación de toda la comunidad, de la cual es deudor en el ejercicio de sus atribuciones. En consecuencia, el filósofo francés considera legítimo el desarrollo de estas tesis

82 Santo Tomás de Aquino, Summa Theologica, I-II, q. 90, a. 4, s. y ad. 2, cit., vol. 2, pp. 706-707: «Por tanto, la institución de la ley pertenece, bien a todo el pueblo, bien a la persona pública que tiene el cuidado del mismo [...] Esta fuerza coactiva [de la ley] radica en el pueblo o en la persona pública que lo representa» y I-II, q. 97, a. 3, ad. 2, cit., vol. 2, pp. 758: «Cuando se trata de una comunidad libre, capacitada para darse leyes...».

83 Santo Tomás de Aquino, De Regimine Principum, I, 6, cit., p. 36.

84 Santo Tomás de Aquino, Summa Theologica, I-II, q. 97, a. 3, ad. 2, cit., vol. 2, p. 758: «[En el supuesto de que la potestad legislativa corresponda a toda la comunidad] el consenso de todo el pueblo expresado en la costumbre vale más en orden a establecer una norma que la autoridad del príncipe, cuya autoridad radica únicamente en que asume la representación del pueblo».

85 Ibid., I-II, q. 105, a. 1, c., cit., vol. 2, p. 864.

86 GalvaO DE Sousa, J. de P., «El pensamiento político de Tomás de Aquino» (trad. E. Cantero,), <http://www.fundacionspeiro.org/verbo/1981/V-197-198-P-833-853.pdf> [consulta: 20-032017], p. 849: «En cuanto al mejor régimen político, [Santo Tomás] no deja de señalar que requiere una cierta participación popular, que se daría, diríamos nosotros, por medio de un auténtico sistema representativo». 
del Doctor Angélico por sus discípulos Cayetano, Belarmino y Suárez, lo cual desembocará en tres consecuencias de singular importancia para el moderno Estado democrático: primera, que el pueblo ostenta un derecho fundamental a gobernarse a sí mismo, con independencia de que designe para ello a determinadas personas como delegados suyos; segunda, dichos representantes son auténticos titulares del poder político y, por tanto, deben mandar y ser obedecidos; y tercera, estos delegados están sujetos al control del pueblo, ante el que deben responder de sus actos conforme a su carácter representativo y vicario ${ }^{87}$.

CAPPELLETI disiente de estas afirmaciones, pues considera dudoso que Santo Tomás hubiera mantenido que el soberano recibía su autoridad del pueblo a través de su consentimiento tácito. No obstante, admite que quienes posteriormente interpretaron su doctrina -especialmente los jesuitas- sí llegaron a dicha conclusión ${ }^{88}$. Según este autor, la admisión del elemento democrático siempre estaría condicionada a un requisito previo: que su intervención fuera la realización más adecuada del bien común en la sociedad ${ }^{89}$.

A título de recapitulación podemos añadir, como señala RECASÉNS, que el elemento democrático en la doctrina del Aquinate se manifiesta principalmente en dos extremos: la comunidad delega el ejercicio del poder en el príncipe, aunque sin perder definitivamente su titularidad originaria, $\mathrm{y}$, como consecuencia de lo anterior, se le reconoce al pueblo la potestad de recuperar dicho poder en caso de ejercicio tiránico o abusivo del mismo por parte de su representante ${ }^{90}$.

\subsection{Concepto de soberanía popular para Santo Tomás}

Una vez que hemos comprobado que el santo dominico prevé como posibilidad que la comunidad política elija a sus representantes y que los gobernantes aparezcan como representantes del pueblo, resulta imprescindible

87 Maritain, J., El hombre y el Estado (trad. J. M. Palacios), Ediciones Encuentro y Fundación Humanismo y Democracia, Madrid, 1983, pp. 150-156.

88 CappelletTi, A. J., «El aristotelismo político de Tomás de Aquino», cit., pp. 204-205.

89 Esta condición se cumple en la actualidad según MARITAIN, J., «Los derechos del hombre y la ley natural» (trad. A. Esquivias), en Los derechos del hombre y la ley natural. Cristianismo y Democracia, Palabra, Madrid, 2001, p. 72: «Pues, si es verdad que la autoridad política tiene como función esencial dirigir a hombres libres hacia el bien común, es normal también que esos hombres libres escojan ellos mismos a quienes tienen la función de dirigirles y de ese modo participen en el control del poder: ésta es la forma más elemental de participación activa en la vida política».

90 ReCASÉNs, L., Historia de las doctrinas sobre el contrato social, cit., p. 6. 
dilucidar si con estas afirmaciones Santo Tomás suscribe una concepción de soberanía popular en términos rousseaunianos.

Para dar una adecuada respuesta a dicho interrogante, hay que tomar en consideración que Santo Tomás no concibe el gobierno popular como un poder absoluto -aunque pueda configurarse como originario en los términos anteriormente expuestos ${ }^{91}$ - sino limitado por los siguientes parámetros:

- No se puede contravenir las normas de Derecho natural por un simple acuerdo de la mayoría de los miembros de la comunidad política ${ }^{92}$.

- Tampoco resulte admisible que la comunidad adopte decisiones que contradigan al bien común, de forma que se conceda el poder a representantes indignos que actúen de forma corrupta con la aquiescencia de los electores ${ }^{93}$. Dentro de este reparo, resulta evidente la alusión a la demagogia como tiranía de unos pocos apoyada en la voluntad de la masa $^{94}$.

Desarrollando las tesis tomistas, MARITAIN afirma que la soberanía, como tal, constituye un poder ilimitado y trascendente que sólo pertenece a Dios. El pueblo, organizado como un cuerpo político, no es soberano sino titular de un derecho natural a gobernarse a sí mismo, el cual ejercita mediante la elección de sus representantes ${ }^{95}$.

Estas afirmaciones nos puede parecer antidemocráticas, especialmente desde la perspectiva de las modernas formulas constitucionales que radican la

91 Nos referimos al principio de que los gobernantes representan o actúan como delegados del pueblo. Sin embargo, conviene no olvidar que, para Santo Tomás, la causa primera del poder político es Dios, como se aprecia en SANTo Tomás DE AQUino, Summa Theologica, II-II, q. 10, a. 11, c., cit., vol. 3, p. 121: «El Gobierno humano proviene del divino y debe imitarle».

92 Ibid., II-II, q. 57, a. 2, ad.2., cit., vol. 3, p. 472: «Pero si algo por sí mismo connota oposición al derecho natural, no puede hacerse justo por la voluntad humana; por ejemplo, si se estableciera que es lícito robar o adulterar».

93 Ibid., I-II, q. 97, a. 1, c. y ad. 3, cit., vol. 2, pp. 755-756: «San Agustín explica esto en I De lib. arb. con el siguiente ejemplo: ... Mas si este mismo pueblo, corrompiéndose poco a poco, cae en la venalidad del sufragio y entrega el mando a los infames y malvados, con razón se les priva del poder de nombrar cargos y retorna este poder al arbitrio de una minoría de hombres honestos [...] la rectitud de la ley es un atributo relativo, que se dice en función del bien común, al que no siempre una misma cosa contribuye de la misma manera, como ya dijimos (sol.). Por eso, en esta materia, la rectitud puede cambiar».

94 Santo Tomás de Aquino, De Regimine Principum, I, 5, cit., p. 30: «Sucede... que degenera en tiranía el gobierno de muchos... porque en las disensiones populares que suscita el gobierno democrático, se ve con frecuencia que uno solo es el que domina a la muchedumbre y usurpa el dominio de la multitud».

95 Maritain, J., El hombre y el Estado, cit., pp. 37-39. 
soberanía nacional y el poder estatal en la voluntad popular ${ }^{96}$. Sin embargo, dicha valoración debe matizarse ya que las leyes fundamentales occidentales, tras la experiencia de la Segunda Guerra Mundial y, especialmente, del régimen nazi en Alemania, incluyeron elementos limitadores del poder de estas mayorías para evitar que, paradójicamente, pudieran adoptar soluciones totalitarias ${ }^{97}$. De hecho, ésa es la función que cumplen las tablas de derechos fundamentales de encabezan nuestras cartas magnas y los tribunales constitucionales, encargados de controlar la sujeción de las leyes aprobadas por los representantes populares a las disposiciones reflejadas en la Constitución escrita.

Un buen ejemplo de la diferencia de la doctrina tomista con la de Rousseau sobre la soberanía popular lo tenemos en su reflexión sobre el derecho de resistencia. En efecto, el Aquinate no admite en ningún caso que el pueblo o una parte del mismo, por vía de sedición, pueda destituir a su capricho al gobernante $^{98}$, al contrario de lo que sostiene el filósofo ginebrino ${ }^{99}$. Sin embargo,

96 Sin embargo, esta tesis de Santo Tomás sobre el peligro de que la mayoría imponga sus reglas, sin respeto al derecho de las minorías, se comparte sustancialmente por un autor tan poco sospechoso de autoritarismo como OrTega y Gasset, J., La rebelión de las masas, Austral, Madrid, 2011 [1930].

97 Rhonheimer, M, Cristianismo y laicidad. Historia y actualidad de una relación compleja, cit., p. 75: «La democracia moderna, de tipo liberal es, en realidad, un 'Estado constitucional democrático': el producto de la democratización del parlamentarismo constitucional de tipo anglosajón, basada en el sufragio universal y en el principio de la mayoría. Y no hay que olvidar que estos elementos, sin los demás [división de poderes, imperio de la ley, limitación del poder] podría dar vida a otra clase de sistema: la democracia plebiscitaria e incluso totalitaria de la tradición de Rousseau, que se revolvía precisamente contra la idea de representación». En contra de la sujeción de la voluntad popular a los mandatos constitucionales se pronuncia expresamente RousSEAU, J. J., El Contrato social (trad. F. De los Ríos), lib. I, cap. VII, Espasa Calpe, Madrid, 2007 [1762], p. 48: «... no hay ni puede haber ninguna especie de ley fundamental obligatoria para el cuerpo del pueblo, ni siquiera el contrato social».

98 Santo Tomás DE Aquino, Summa Theologica, II-II, q. 42, a. 2, c. 3, vol. 3, cit., pp. $345-$ 346. «Como hemos expuesto (a.1), la sedición se opone a la unidad de la multitud, es decir, a la unidad del pueblo, de la ciudad o del reino. Pero, en palabras de San Agustín, en II De civ. Dei, la expresión pueblo, en opinión de los sabios, designa no el conjunto de la multitud, sino el cuerpo asociado con la anuencia del derecho y la comunión utilitaria. Es, por lo mismo, evidente, que la unidad a la que se opone la sedición es la unidad de derecho y de utilidad común. En consecuencia, la sedición se opone a la justicia y al bien común. Por eso la sedición es, por naturaleza, pecado mortal».

99 Rousseau, J. J., El Contrato social, cit., pp. 127: «... el acto que instituye el gobierno no es un contrato, sino una ley; que los depositarios del poder ejecutivo no son los dueños del pueblo, sino sus oficiales; que puede nombrarlos y destituirlos cuando le plazca [...] Por tanto, cuando sucede que el pueblo instituye un gobierno hereditario, sea monárquico en una familia, sea aristocrático en una clase de ciudadanos, no contrae un compromiso, sino que da una forma provisional a la administración, hasta que le place ordenarla de otra manera». Resulta evidente la contradicción 
basándose en la primacía del bien común, Santo Tomás considera lícita la posibilidad de resistir y derrocar a una autoridad política que, por sus desaforados abusos, cause más daño al bien de la comunidad que la propia rebelión ${ }^{100}$. En este sentido, no puede entenderse que Santo Tomás sea un partidario acérrimo de doctrinas legitimistas del poder instituido, aun siendo muy consciente de los peligros que conllevan las revueltas ${ }^{101}$.

Por tanto, podemos concluir que el Doctor Angélico no aceptaría en ningún caso una soberanía popular ilimitada, como expresión de una suprema e incontestable voluntad general, de tintes claramente totalitarios ${ }^{102}$. Pero no cabe duda que su doctrina podría incardinarse dentro de la corriente partidaria de un régimen político de elección democrática representativa sujeto a los límites del respeto a la dignidad del sujeto y a los derechos fundamentales, entendidos éstos últimos como la moderna concreción de las prescripciones de la ley natural y las exigencias del bien común ${ }^{103}$.

entre el pensameneto del filósofo ginebrino y las restricciones a la soberanía popular que defiende LoCKe, J., Segundo Tratado sobre el Gobierno Civil, cit., n. 153, pp. 151: «Cuando el poder legislativo ha depositado en otras manos el poder de ejecución, puede todavía volverlo a quitar de esas manos, si encuentra una causa que lo justifique, y castigar a quienes hayan hecho mala administración de tales leyes» (la cursiva es nuestra).

100 Santo Tomás De Aquino, Summa Theologica, II-II, q. 42, a. 2, ad. 3, vol. 3, cit., p. 346: «El régimen tiránico no es justo, ya que no se ordena al bien común, sino al bien particular de quien detenta el poder, como prueba el Filósofo en III Polit. en VIII Ethic. De ahí que la perturbación de ese régimen no tiene carácter de sedición, a no ser en el caso de que el régimen del tirano se vea alterado de una manera tan desordenada que la multitud tiranizada sufra mayor detrimento que con el régimen tiránico. El sedicioso es más bien el tirano, el cual alienta las discordias y sediciones en el pueblo que le está sometido, a efectos de dominar con más seguridad. Eso es propiamente lo tiránico, ya que está ordenado al bien de quien detenta el poder en detrimento de la multitud».

101 Acerca de los gravísimos peligros de las rebeliones populares contra el tirano, tales como la reacción violenta del monarca que supera el golpe de estado o el mayor despotismo de los nuevos gobernantes, vid. SANTO TOMÁs DE AQuino, De Regimine Principum, I, 6, cit., pp. 31-36.

102 Rhonheimer, M., Cristianismo y laicidad. Historia y actualidad de una relación compleja, cit., p. 81: «Éstos [los discípulos de Rousseau] propalaban una soberanía popular absoluta, no limitada de ninguna manera por consideraciones previas de carácter moral y jurídico de derecho natural: sostenían el derecho del pueblo a echar abajo a cualquier gobierno en todo momento» y RECASÉNS, L., Historia de las doctrinas sobre el contrato social, cit., p. 7: «En cambio no parece que santo Tomás admitiera que una vez verificado el contrato político con el príncipe (mediante el que se le instituye como tal) y siempre que éste lo cumpla, el pueblo pueda revocarlo unilateralmente por haber variado de opinión, por estimar que le conviene la implantación de otro régimen».

103 FINNIS, J., Ley Natural y Derechos Naturales, cit. p. 249, considera que una de las principales ventajas del uso del lenguaje de los derechos humanos es que los mismos representan concreciones del bien común, dirigidas a la plena realización del ser humano en la sociedad contemporánea. 
En conclusión, la doctrina tomista comparte la idea de una soberanía popular expresada por vía parlamentaria y vinculada al pacto constitucional, propia de Locke, pero se opone al modelo de democracia asamblearia y populista que defiende Rousseau ${ }^{104}$.

\section{3. ¿Es compatible la doctrina tomista con la idea del contrato social?}

No resulta extraño encontrar en diversos autores la opinión de que el contrato social resulta inadmisible dentro de los esquemas del pensamiento del Aquinate ${ }^{105}$.

Se argumenta al efecto que la teoría contractualista resulta propia del iunaturalismo racionalista y el pensamiento liberal del siglo XVII en adelante. Según la misma, los individuos, que vivían un primitivo -y ficticio ${ }^{106}$ «estado

${ }^{104}$ En contra de esta afirmación se pronuncia, RECASÉNS, L., Historia de las doctrinas del contrato social, cit., pp. 27-29, al defender que Rousseau constituye un nuevo momento o una fase ulterior en el desarrollo del pensamiento escolástico sobre la materia, cuya principal aportación es considerar que el contrato social no es un dato empírico o histórico sino un criterio ideal para juzgar racionalmente la legitimidad de los sistemas políticos.

105 Bоввіо, N., El tiempo de los derechos, cit., pp. 161-162: «Para que pudiese producirse esta inversión del punto de vista, de la que nace el pensamiento político moderno, era necesario que fuese abandonada la teoría tradicional que en otra ocasión he definido como modelo aristotélico, según la cual el hombre es un animal político que nace en un grupo social... Era necesario que se presupusiese la existencia de un estado anterior a toda forma organizada de sociedad, un estado originario, que por su originalidad debiese ser considerado como el lugar del nacimiento y el fundamento del estado civil [...] Se trataría nada menos que de dar cuenta del nacimiento de la concepción individualista de la sociedad y de la historia que es la antítesis radical de la concepción organicista, según la cual, repitiendo una afirmación de Aristóteles... el todo (la sociedad) es anterior a sus partes. Derribando esta relación entre el todo y las partes, según la concepción individualista de la historia, el individuo viene antes, la sociedad viene después. La sociedad está para el individuo no el individuo para la sociedad». En idéntico sentido se pronuncian HAARSCHER, G., Philosophie des droits de l'homme, Univesidad de Bruselas, Bruselas, 1987, p. 12, PÉREZ LuÑo, A. E., La Filosofía del Derecho en perspectiva histórica, cit., p. 81 y CONTRERAS, F. J., «Los derechos humanos como versión de la ley natural (I)», en AA.VV. (CONTRERAS, F. J. [dir.]), El sentido de la libertad. Historia y vigencia de la ley natural, cit., pp. 146-147.

106 FERNÁNDEZ, E., «El contractualismo clásico (siglos XVII y XVIII) y los derechos naturales», Anuario de Derechos Humanos, vol. 2 (1983), p. 67: «... la falta de fundamentación histórica no constituyó para los teóricos del contrato social una creencia errónea, sino que en la mayor parte de los casos se trata de un presupuesto perfectamente asumido. El paso del estado de naturaleza al de la sociedad a través de un pacto se utiliza como una hipótesis y no como si se tratara de un hecho histórico realmente acaecido», PÉREZ LuÑo, A. E., La Filosofía del Derecho en perspectiva histórica, cit., p. 80: «Para Rousseau, al igual que posteriormente para Kant y otros contractualistas, el estado de naturaleza y el contrato social no poseen un carácter empírico o histórico, sino 
de la naturaleza», donde no existía un Estado que les sujetara con su vis coactiva, acordaron mediante un pacto delegar parte de su ilimitada libertad en el titular del gobierno con la finalidad y condición de que asumiera la tutela de sus naturales derechos, creando así el nuevo «estado de sociedad política» ${ }^{107}$.

Dicho planteamiento se interpreta por un amplio sector doctrinal como incompatible con la visión comunitario-organicista que se deriva de la enseñanza aristotélico-tomista que, al fundarse en la natural sociabilidad del ser humano, implica la necesidad de una autoridad que rija los destinos de dicha comunidad ${ }^{108}$. Por tanto, la denominada philosophia perennis contrapone el carácter natural de la organización política a la artificiosidad propia de las corrientes ilustradas.

Sin embargo, a nuestro modesto entender, esta oposición, que se derivaría de la decidida apuesta de la doctrina tomista en favor de tesis comunitaristas o corporativas frente al individualismo liberal propio de ciertas corrientes del contrato social, puede ser salvada utilizando determinadas claves que pasamos a exponer.

En primer lugar, el argumento de la mencionada incompatibilidad ignora un dato esencial: sólo es posible la suscripción de un contrato dentro de un previo contexto social. Como bien señala ORTEGA Y GASSET ${ }^{109}$, precisamente por el hecho de que los seres humanos tenemos la inclinación de vivir en sociedad es por lo que necesitamos llegar a un acuerdo. El contrato constituye una relación jurídica cuyo componente esencial es la bilateralidad o la pluralidad, es decir, la coexistencia entre varios sujetos. Ningún sentido tendría, pues, el denominado

que tiene una dimensión contrafáctica y actúan como criterio ideal de legitimación política» y, en relación con las tesis neocontractualistas, RAWls, J., Teoría de la fusticia (trad. M. D. González), Fondo de Cultura Económica, Madrid, 2006, p. 25: «En la justicia como imparcialidad, la posición original de igualdad corresponde al estado de naturaleza en la teoría tradicional. Por supuesto que la posición original no está pensada como un estado de cosas históricamente real, y mucho menos como una posición primitiva de la cultura. Se considera como una situación puramente hipotética...».

107 Seguimos, en lo esencial, el relato de Locke, J., Segundo Tratado sobre el Gobierno Civil, cit., nn. 4-15, pp. 10-21. Por contra, para Hobbes, la finalidad del contrato suscrito será la de asegurar la paz y la vida de los súbditos por el monarca absoluto, para lo cual se otorga a éste un poder ilimitado.

108 Santo Tomás De Aquino, Summa Theologica, I, q. 96, a. 4, c.,cit., vol. 1, p. 854: «... el hombre es por naturaleza animal social, y en el estado de inocencia vivieron en sociedad. Ahora bien, la vida social entre muchos no se da si no hay al frente alguien que los oriente al bien común, pues la multitud de por sí tiende a muchas cosas; y uno sólo a una».

109 OrTega., J, La rebelión de las masas, cit., p. 45. 
contrato social si los individuos fuéramos «robinsones» autosuficientes aislados en nuestras propias islas. Las personas somos seres sociales que necesitamos de pactos con los que fijar las reglas de convivencia en comunidad.

En segundo término, la misma idea de pacto social o acuerdo como fórmula para la designación del gobernante no resulta en absoluto ajena a Santo Tomás ${ }^{110}$. Como ya hemos expuesto, el régimen mixto -que se plantea como el más perfecto en la Summa-implica necesariamente la concurrencia de un acuerdo del cual se deriva, entre otras consecuencias, la posición del príncipe como representante o delegado del pueblo para ostentar el gobierno y la necesidad de que todos los integrantes de la comunidad política puedan ser, simultáneamente, electores y elegidos para las distintas magistraturas ${ }^{111}$.

Una tercera clave interpretativa que no se debe obviar es la paradoja de que uno de los máximos exponentes del contrato social, el británico Locke, defiende de forma expresa el carácter natural de la sociabilidad humana ${ }^{112}$. Sin embargo, para contrarrestar los argumentos de los teóricos de la monarquía absoluta, que pretendían legitimar la autoridad de los mismos en un presunto derecho natural o divino de Adán a gobernar sobre sus descendientes, utiliza la hipótesis del contrato social y el estado de naturaleza como requisito sine qua non para la creación de la sociedad política que, con anterioridad a ella, no existía ${ }^{113}$. Como se puede apreciar, la doctrina del contrato social persigue justificar una forma

110 FinnIs, J., Aquinas. Moral, Political and Legal Theory, cit., p. 266: «La idea de reciprocidad, mutualidad y 'pacto' equitativo entre legisladores y legislados juega un papel significativo en la teoría del gobierno de Aquino»; y Mirete, J. L., «Pacto social en Sto. Tomás de Aquino», Anales de Derecho, n. ${ }^{\circ} 16$ (1998), p. 160, considera que Santo Tomás atribuía al príncipe la facultad de promulgar las leyes y al pueblo la de sancionar, sin perjuicio de que el sentido racional que debía tener la norma constituyera un criterio común a ambos.

111 Santo Tomás De Aquino, De Regimine Principum, I, 6, cit., p. 37: «... porque conduciéndose como un mal príncipe en el gobierno del Estado, debiendo consagrarse a su bien y prosperidad como cumple a su misión, se hizo acreedor a que sus súbditos rompieran el pacto que con él hicieron», Summa Theologica, I-II, q. 90, a. 4, ad. 2, cit., vol. 2, p. 707: «Esta fuerza coactiva [de la ley] radica en el pueblo o en la persona pública que lo representa» y Summa Theologica, I-II, q. 105, a. 1, c., cit., vol. 2, p. 864: «La mejor constitución en una ciudad o nación es aquella en que uno es el depositario del poder y tiene la presidencia sobre todos, de tal suerte que algunos participen de ese poder y, sin embargo, ese poder sea de todos, en cuanto que todos pueden ser elegidos y todos toman parte en la elección» (la cursiva es nuestra).

112 Locke, J., Segundo Tratado sobre el Gobierno Civil, cit., n. 77, p. 79: «Dios, al hacer del hombre una creatura que, según el juicio divino, no era bueno que estuviese sola, lo puso bajo fuertes obligaciones, tanto de necesidad como de convivencia, que lo inclinaban a vivir en sociedad; y le otorgó también un entendimiento y un lenguaje que le permitieran continuar su condición sociable, y disfrutarla. La primera sociedad que se creó fue la de hombre y mujer...».

113 Ibid., nn. 1 y 89, pp. 7-8 y 88-89. 
de gobierno que proteja los derechos de los ciudadanos frente a los abusos del poder y no la negación del carácter comunitario de la convivencia humana ${ }^{114}$. De ahí que se admita sin problema la existencia de una sociedad familiar que preceda y se distingua claramente de la de carácter político o civil.

Finalmente, tampoco deben olvidarse experiencias contemporáneas de coordinación entre los dos tesis que estamos analizando. La Declaración Universal de los Derechos Humanos nos remite, tanto en su procedimiento de elaboración por consenso como, sobre todo, en su aprobación mediante el voto favorable de casi todas las naciones del planeta, a la idea de un contrato social a escala mundial. Sin embargo, dicho texto, en el Preámbulo, declara solemnemente que todo el género humano pertenece a una misma familia y su artículo 29, párrafo primero, insiste en que toda persona tiene deberes para con la comunidad, ya que sólo en ella puede desarrollar libre y plenamente su personalidad, lo cual nos reconduce a la evidencia del carácter social inherente a todo individuo ${ }^{115}$.

De lo antedicho resulta una clara relación entre la sociabilidad humana y el acuerdo entre los miembros de la comunidad política como elemento esencial para regirla. Probablemente, la contraposición entre ambos datos proviene de una confusión entre dos realidades diferentes. Una cosa es la creación de la sociedad o vida comunitaria, que se produce naturalmente y cuyo origen se pierde en la noche de los tiempos, y otra muy distinta la configuración concreta del régimen de gobierno o forma política del Estado, que dependerá en última instancia de los acuerdos o convenios que coyunturalmente se adopten en cada época ${ }^{116}$.

114 Osuna, A., Teoría de los derechos humanos. Conocer para practicar, San Esteban-Edibesa, Salamanca-Madrid, 2001, p. 91: «Lo que importaba era proclamar que el individuo y su libertad están por encima de todo orden político y autoridad constituida. En consecuencia, el derecho natural del individuo es anterior a todas las leyes políticas emanadas de la autoridad. Con ello se inflingía un golpe mortal a toda forma absolutista de poder, que era lo que pretendía Locke. Bastaba con resaltar ese matiz presocial del derecho natural para borrar de la historia las ideas políticas absolutistas».

115 Ambos rasgos se pusieron de manifiesto por uno de los máximos responsables de la Declaración de 1948, vid. Humphrey, J., «La Declaración internacional de derechos. Estudio crítico», en AA.VV., Los fundamentos filosóficos de los derechos bumanos (trad. G. Baravalle), Serbal, Barcelona, 1985 , pp. 67 y 70.

116 ORTEGa Y GASSET, J., La rebelión de las masas, cit., p. 200: «... el Estado no es una forma de sociedad que el hombre se encuentra dada y en regalo, sino que necesita fraguarla penosamente. No es como la horda o la tribu y demás sociedades fundadas en la consanguinidad que la naturaleza se encarga de hacer sin colaboración con el esfuerzo humano»; y CORDERO, J., en su edición 
La relación entre ambos fenómenos se puede explicar de forma satisfactoria utilizando las categorías tomistas. Efectivamente, el hecho de que las personas estemos naturalmente llamados, según nuestra naturaleza, a vivir en comunidad y, consiguientemente, se requiera la existencia de una persona u órgano responsable que adopte las decisiones que afecten al colectivo, constituye un dato propio de ley natural como inclinación innata que se aprecia a través del análisis de la historia. Sin embargo, la necesidad de acuerdo expreso o tácito de la sociedad para establecer cada concreta forma de gobierno implica una determinación posterior que entra dentro del campo de los principios de derecho natural ${ }^{117}$. Finalmente, el sistema concreto de elección o legitimación del poder político en cada momento histórico -monarquía, república, democracia asamblearia, representativa o censitaria, etc.- queda al arbitrio de lo que el Aquinate considera como propio de la ley humana o, según el lenguaje moderno, del derecho positivo ${ }^{118}$.

En consecuencia, si bien es cierto que no se puede asimilar de forma absoluta -pues implicaría un evidente anacronismo- el contrato social propio de los ilustrados con el que se mantiene por el Aquinate ${ }^{119}$, no lo es menos que una oposición radical entre ambos, hasta el punto de implicar la forzosa configuración de sistemas políticos totalmente contrapuestos, tampoco responde a la realidad. La diferencia básica entre ambas posturas radica en que los ilustrados basan el contrato social en un hipotético «estado de la naturaleza» donde los individuos vivían como átomos aislados sin relacionarse entre sí, mientras que Santo Tomás considera dicho pacto como el instrumento más eficaz para

crítica de Vitoria, F., Relectio de Potestae Civili. Estudios sobre su Filosofía Politica, cit., p. 355, n. 43: «... las modernas teorías del contrato social... tampoco contemplan la posibilidad de no vivir en sociedad, sino sólo la de hacerlo bajo una u otra modalidad de organización política».

117 Para realizar una adecuada distinción entre ley natural y derecho natural, frecuente y erróneamente confundidas, seguimos a Ollero, A., «Hermenéutica jurídica y ontología en Tomás de Aquino», cit., pp. 292 y 296-297, quien defiende que frente a la ley natural, abstracta e inmutable en sus contenidos ético-jurídicos, el derecho natural es histórico, concreto y surge como primeras determinaciones de los genéricos mandatos contenidos en aquélla.

118 Santo Tomás De Aquino, Summa Theologica, I-II, q. 91, a. 3, c., cit., vol. 2, p. $712 \ll . .$. en el orden práctico, la razón humana ha de partir de los preceptos de la ley natural como de principios generales e indemostrables, para llegar a sentar disposiciones más particularizadas. Y estas disposiciones particulares descubiertas por la razón humana reciben el nombre de leyes humanas, supuestas las demás condiciones que se requieren para constituir la ley».

119 A juicio de Haarscher, G., Philosophie des Droits de l'bomme, cit., p. 73, Santo Tomás parte de una consideración holística del pueblo, entendido como comunidad, corporación o grupo social, cuando atribuye su representación al príncipe, mientras que el pensamiento ilustrado entiende que el pacto se celebra de forma individual con cada ciudadano como sujeto independiente. 
la adecuada consecución del bien común ${ }^{120}$. De esta forma el Aquinate supera una interpretación solipsista del individuo en la vida social, pero sin renunciar, frente a cualquier tentación colectivista, a la irreductible dignidad de la persona como exigencia propia dicho bien.

En este sentido, no resultaría histórica ni filosóficamente exacto considerar que, como contrapunto al origen del Estado liberal basado en las teorías del contrato social -presupuesto verdadero-, la doctrina de Santo Tomás constituyó el fundamento ideológico de las monarquías absolutas de origen divino -conclusión errónea-.

Y ello por varias razones: la primera es que el proceso de concentración de poder que generó el absolutismo surgió siglos después del fallecimiento del Aquinate; la segunda radica en que los seguidores del pensamiento tomista, desarrollando su doctrina, también aplicaron la teoría pactista (Vitoria ${ }^{121}$, Suárez ${ }^{122}$, Las Casas ${ }^{123}$ ) y llegaron a justificar el derecho de resistencia o, en

${ }^{120}$ También se formuló una conciliación entre la doctrina aristotélico-tomista y el contrato social por MARITAIN, J. «Los derechos del hombre y la ley natural», cit., pp. 71-72: «La célebre frase de Aristóteles de que el hombre es un animal político no significa solamente que el hombre está hecho naturalmente para vivir en sociedad, significa también que el hombre pide naturalmente llevar una vida política y participar activamente en la vida política. Sobre este postulado de la naturaleza humana reposan las libertades políticas y los derechos políticos, especialmente el derecho al sufragio... Un estado de civilización donde los hombres, en tanto que personas individuales, designen por elección libre a quienes detentan la autoridad y donde la nación controla al Estado, es por sí misma una situación más perfecta».

121 Copleston, F., Historia de la Filosofía, vol. 2, tomo 3, cit., p. 275, señala que Vitoria seguía, en esencia, la teoría del contrato aunque no llegó a explicitarla. Por contra, Llano, F., «Humanismo renacentista. Razón universal y sociedad humana en el pensamiento de Francisco de Vitoria», Derechos y Libertades, n. ${ }^{\circ} 34$ (2016), p. 102, mantiene que el fundador de la Escuela de Salamanca, debido a su doctrina acerca del origen divino y natural del Estado, no puede considerarse un precursor del contractualismo.

122 Copleston, F., Historia de la Filosofía, vol. 2, tomo 3, cit., p. 314 y 317: «Suárez afirma también que el establecimiento de un determinado gobierno depende del consentimiento de la comunidad política que confiere la soberanía... es indudable que habla explícitamente de un pacto o convenio entre el rey y el reino [...] Suárez afirma así el derecho de resistencia, que es una consecuencia lógica de su doctrina del origen y transferencia de la soberanía. Es indudable que no alentó en modo alguno revueltas innecesarias; pero es fácilmente comprensible que su obra sobre la fe católica pareciese ofensiva a Jacobo I de Inglaterra, que creía en el derecho divino de los reyes y en el principio de legitimidad».

${ }^{123}$ Llano, F., «La influencia de Santo Tomás en los clásicos españoles del Derecho natural», Actas del II Congreso de Filosofía Medieval, Sociedad de Filosofía Medieval, Zaragoza, 1996, pp. 363-364: «En este precedente lascasiano a la fundamentación pactista del poder de las doctrinas democráticas de Locke, Rousseau o Kant, podría reconocerse claramente la inspiración en aquellos pasajes de la Summa Theologica referidos a las leyes injustas que vulneran el Bien Común al que en principio deberían ordenarse... [lo que] unido a los comentarios 
casos muy extremos, el asesinato del déspota ${ }^{124}$, y, en tercer y último lugar, tampoco puede ignorarse la existencia de una tradición del contrato social de sesgo absolutista (Grocio, Pufendorf, Spinoza y Hobbes, si bien cada uno en diferente grado $)^{125}$.

\section{El estado social en el pensamiento de Santo Tomás de Aquino}

\subsection{Función social de la propiedad}

La doctrina del Aquinate sobre la propiedad privada pivota sobre dos pilares fundamentales: la apropiación de bienes por los individuos constituye un atributo propio de su naturaleza (criterio de poder de gestión y disposición), pero los mismos deben ser empleados de una forma adecuada para subvenir no sólo las necesidades propias sino también las de la comunidad (criterio de uso $)^{126}$. En el fondo de dicha diferencia se atisba la distinción entre titularidad y ejercicio del derecho.

De acuerdo con el primero de los asertos, la propiedad se configura como un auténtico derecho natural -aunque el Doctor Angélico no utilice literalmente dicha expresión ${ }^{127}$ - por las siguientes razones ${ }^{128}$ :

- El interés y el cuidado por lo propio es mucho mayor que el que se muestra por lo que pertenece al colectivo. Utilizando una frase hecha, diríamos que lo que es de todos acaba siendo de nadie.

dedicados a la tiranía en la misma Summa Theologica o en De Regimine Principum, entre otras, nos lleva a concluir que no sería apresurado atisbar cierta reminiscencia tomista en la doctrina española del derecho a la resistencia encarnada en las figuras de Roa Dávila, Francisco de Suárez y Juan de Mariana».

${ }^{124}$ No obstante, conviene aclarar que el Doctor Angélico, si bien llegó a justificar el cambio de régimen ante un ejercicio radicalmente abusivo del poder, no aprueba el tiranicidio en sus obras de madurez, vid. Santo Tomás DE Aquino, De Regimine Principum, I, 6, cit., pp. 34-36.

125 Vid. FERNÁNDEZ, E., «El contractualismo clásico (siglos XVII y XVIII) y los derechos naturales», cit., pp. 79-87.

126 SANTO Tomás DE AQuino, Summa Theologica, II-II, q. 66, a. 2, c., cit., vol. 3, p. 544.

127 Ibid., II-II, q. 66, a. 1, c., p. 543:«Este dominio natural sobre las demás criaturas, que compete al hombre por su razón, en la que reside la imagen de Dios, se manifiesta en la misma creación del hombre».

128 Ibid., II-II, q. 66, a. 2, c., p. 544. Por su parte, VAllet DE GOYTISOLO, J. B., «La propiedad en Santo Tomás de Aquino», Revista de Estudios Políticos, n. ${ }^{\circ}$ 195-196 (1974), pp. 72-73, propone la siguiente clasificación de los argumentos del Doctor Angélico en favor de la propiedad privada: económico, sociológico, político, de dinámica social y ético. 
- Igualmente hay que ponderar una razón de eficacia en el aprovechamiento los bienes temporales. La concurrencia de una pluralidad de titulares implica una mayor dificultad en la dirección que, a su vez, influye negativamente en la administración de los bienes y la obtención de su adecuado rendimiento.

- Por último, las querellas y conflictos acerca de los derechos y obligaciones de cada comunero en los bienes de propiedad colectiva crecen exponencialmente, poniendo así en peligro la paz social. Lo mismo sucedería a la hora de distribuir los beneficios obtenidos, surgiendo disputas inacabables en cuanto de los criterios de reparto.

De acuerdo con ello, el santo dominico se adscribe a la postura favorable a la propiedad, como ya se apuntó por San Agustín y Aristóteles ${ }^{129}$ y en contra de quienes la rechazan, como Platón y San Ambrosio.

Sin embargo, a renglón seguido, aplica el segundo de los principios, insistiendo en la necesidad de que el uso que se dé a los bienes que pertenecen legítimamente a cada propietario estén sujetos a un deber originario y general: ponerlos en común con las demás personas que necesiten de ellos y destinarlos a actos virtuosos ${ }^{130}$.

De esta forma se verifica la unión inescindible entre el derecho al goce y disposición de la propiedad -titularidad- y el deber de uso. Es más, será precisamente este uso «moralmente» adecuado de lo que está bajo nuestro dominio lo que justifique la necesidad de considerarlo como propio ${ }^{131}$, ya que sólo se puede actuar virtuosamente cuando se comparte algo que nos pertenece y de lo que podemos disponer con libertad. Resulta evidente que para realizar un acto bueno se debe actuar con libre albedrío, ya que los llevados a cabo bajo coacción no pueden ser objeto de calificación moral.

129 Una interesante defensa de la propiedad privada, sin excluir la común en supuesto excepcionales, se puede consultar en ARISTÓTELES, Política, II, 5, cit., pp. 99-105.

${ }^{130}$ Santo Tomás DE Aquino, Summa Theologica, II-II, q. 66, a. 2, c., cit., vol. 3, p. 544: «En segundo lugar, también compete al hombre, respecto de los bienes exteriores, el uso de los mismos; y en cuanto a esto no debe tener el hombre las cosas exteriores como propias, sino como comunes, de modo que fácilmente dé participación de éstas en las necesidades de los demás».

131 Santo Tomás De Aquino, De Regimine Principum, I, 15, cit., p. 96-97: «Para que un hombre sea de buena vida y costumbre necesita de dos cosas... otra secundaria y como instrumental, a saber, cantidad bastante de bienes corporales de cuyo uso se necesita para el ejercicio práctico de la virtud». En este punto se pone de manifiesto la influencia de ArISTÓTELES, Política, II, 5, cit., p. 101: «Por otra parte, el hacer favores y socorrer a los amigos, huéspedes camaradas, es lo más agradable, y esto sólo se realiza gracias a la propiedad privada». Santo Tomás, evidentemente, enriquece este argumento con la versión sobrenatural propia de la fe cristiana. 
Por tanto, la raíz de la propiedad privada se encuentra íntimamente ligada al deber de un uso de la misma en beneficio de la comunidad. Aquí encontramos, de nuevo, una semilla de modernidad en el Aquinate, quien formula el «protoconcepto» de función social ${ }^{132}$.

Desde esta perspectiva, el dominico se encuentra más cercano a una visión social de la propiedad que a la radicalmente individualista ${ }^{133}$.

Siguiendo esta línea, MARITAIN defenderá que la propiedad privada, instrumento imprescindible para la protección de la vida y la libertad del ser humano, se encuentra «enraizada» en el Derecho natural, que el derecho de los particulares a la apropiación de los medios de producción se configura como un principio del Derecho de gentes y, finalmente, que la determinación de los diversos modo de adquirir el dominio constituye una materia propia del derecho positivo ${ }^{134}$.

Como hemos intentado demostrar, Santo Tomás defiende una visión profundamente social del derecho a la propiedad privada. La razón que le impulsa a ello es obvia: considera contrario al deber de justicia que existan personas sin los bienes necesarios para poder desarrollar sus potencialidades ${ }^{135}$. De

132 Dicho en términos de Derecho positivo vigente, el Aquinate se identificaría más con el actual artículo 33 de la Constitución española que con el 348 del Código civil, y ello por entender que la función social no es un límite extrínseco a la propiedad sino un elemento indispensable e inherente a la misma, como expone la Sentencia del Tribunal Constitucional 37/1987, de 26 de marzo (RTC 1987 37), FD 8. «Pero este argumento no es convincente. En el fondo del mismo subyace una vez más una concepción de la propiedad privada como institución unitaria, regulada en el Código civil, que sólo admite limitaciones externas a su libre ejercicio en virtud de Leyes especiales. Por el contrario, como se ha expuesto, el derecho a la propiedad privada que la Constitución reconoce y protege tiene una vertiente institucional, precisamente derivada de la función social que cada categoría o tipo de bienes sobre los que ejerce el señorío dominical está llamado a cumplir [...] Asî́ ocurre en el caso de la propiedad urbana, cuyas Leyes de ordenación... establecen por sí mismas o por remisión a los instrumentos normativos del planeamiento, los deberes y límites intrínsecos que configuran la función social de la propiedad del suelo, desde el punto de vista de la ordenación del territorio». De hecho, FinNIs, J., Ley Natural y Derechos Naturales, cit. p. 200, n. 13, relaciona las enseñanzas de Santo Tomás -y Aristóteles- con el art. 14 de la Ley Fundamental de Bonn, precedente directo de nuestra Carta Magna en esta materia.

133 Copleston, F., El pensamiento de Santo Tomás, Fondo de Cultura Económica, México, 1960, p. 161. «Representar a santo Tomás como un partícipe en las controversias políticas del siglo XIX sería un anacronismo. Pero sí podemos decir que la política de laissez-faire no sería compatible con su concepción sobre el propósito y función de la sociedad y el gobierno políticos. La tarea del Estado es producir activamente las condiciones en que pueda vivirse una vida humana plena».

${ }^{134}$ MARITAIN, J., «Los derechos del hombre y la ley natural», cit., pp. 62-63.

135 Santo Tomás De Aquino, Summa Theologica, II-II, q. 32, a. 6, c., cit., vol. 3, p. 296: «Sería, por el contrario, un desorden si se privara de sus bienes propios para dárselos a otro hasta llegar al extremo de que con el remanente no pudiera desenvolver adecuadamente su vida conforme al 
este modo, se muestra como un auténtico precursor de los llamados derechos sociales. Y esto no es una afirmación retórica: la Doctrina social de la Iglesia Católica se apoyó en los criterios del Aquinate para formular su enseñanza sobre el carácter social de la propiedad ${ }^{136}$, la cual fue asimilada por los ordenamientos y gobernantes de las naciones iberoamericanos que, de forma tan importante como poco reconocida, influyeron en la plasmación de los derechos económicos y sociales en la Declaración Universal de $1948^{137}$.

\subsection{Fusticia distributiva}

Otro de los conceptos iusfilosóficos imprescindibles para la formación del Estado social es la necesidad de una justicia distributiva, la cual también fue desarrollada en la obra de Santo Tomás.

Siguiendo la tradicional clasificación entre los tipos de justicia, el Aquinate distingue entre la justicia legal y la particular y, dentro de la segunda, di-

estado y dificultades que se presenten: nadie debe vivir indecorosamente», y De Regimine Principum, I, 15, cit., p. 97. Otra expresiones acerca del carácter relativo de la propiedad en relación con otros bienes de la persona la podemos observar en su doctrina sobre licitud del robo en caso de necesidad extrema -el hurto famélico- de acuerdo con exigencias de justicia, recogida en Summa Theologica, II-II, q. 67, a. 2, c., ad. 2 y 3, cit., vol. 3, pp. 549.

136 LEÓN XIII, Rerum Novarum, 15 de mayo de 1891, 17. «Sobre el uso de las riquezas hay una doctrina excelente y de gran importancia, que, si bien fue iniciada por la filosofía, la Iglesia la ha enseñado también perfeccionada por completo y ha hecho que no se quede en puro conocimiento, sino que informe de hecho las costumbres. El fundamento de dicha doctrina consiste en distinguir entre la recta posesión del dinero y el recto uso del mismo. Poseer bienes en privado, según hemos dicho poco antes, es derecho natural del hombre, y usar de este derecho, sobre todo en la sociedad de la vida, no sólo es lícito, sino incluso necesario en absoluto. 'Es lícito que el hombre posea cosas propias. Y es necesario también para la vida humana'. Y si se pregunta cuál es necesario que sea el uso de los bienes, la Iglesia responderá sin vacilación alguna: 'En cuanto a esto, el hombre no debe considerar las cosas externas como propias, sino como comunes; es decir, de modo que las comparta fácilmente con otros en sus necesidades'. De donde el Apóstol dice: 'Manda a los ricos de este siglo... que den, que compartan con facilidad'». Las dos citas utilizadas por el Romano Pontífice fueron tomadas del libro II-II de la Summa Theologica.

137 Glendon, M. A., «El crisol olvidado: la influencia latinoamericana en la idea de los derechos humanos universales», Persona y Derecho, n. ${ }^{\circ} 51$ (2004), pp. 103-123, realiza una ilustrativa exposición sobre el importante ascendiente de la Declaración Americana de Deberes y Derechos del Hombre de Bogotá sobre su homónima universal, así como la labor de los políticos socialdemócratas, democristianos y socialcristianos en la consagración de los derechos económicos y sociales, desmontando así el falso mito de la decisiva aportación de los países del bloque soviético para incluir tales derechos en el texto aprobado por la Asamblea General de las Naciones Unidas. 
ferencia la conmutativa y la distributiva. Ésta última es definida como aquella relación entre el todo -la comunidad-y las partes -personas que la integran-, en virtud de la cual se distribuyen proporcionalmente los bienes comunes ${ }^{138}$.

La cuestión que se plantea a continuación es la de identificar el criterio para proceder a dicho reparto. En principio se hace referencia, de forma genérica, a la expresión «preponderancia». La concreción del término permite varias soluciones: según la virtud, la riqueza o la igualdad ${ }^{139}$. Pero en todas ellas surge un elemento común: esta justicia no es expresión de una situación de homogeneidad sino que discrimina según el término de distribución o, de acuerdo con la terminología aristotélica, en virtud de una proporción geométrica y no aritmética ${ }^{140}$.

HERVADA señala que la justicia distributiva en relación con el reparto de bienes no responde a un criterio de identidad o equivalencia perfecta, sino a una igualdad proporcional que toma en consideración dos parámetros: la finalidad de los bienes y la relación de los sujetos con dicha finalidad ${ }^{141}$. Por su parte, FINNIS distingue cinco criterios de reparto que deben combinarse, según cada caso concreto, en el ámbito de la justicia distributiva: el principal entre ellos es la necesidad de bienes humanos básicos, a los que siguen los de función -entendido como necesidad respecto a los roles y responsabilidades dentro de la comunidad-, capacidad para aprovechar los recursos según el progreso de cada individuo, méritos y esfuerzos de aportación realizados por cada ciudadano y, por último, la creación o aceptación de riesgos inevitables ${ }^{142}$.

Este criterio de justicia nos lleva al estudio de una figura íntimamente ligada al mismo: los impuestos que deben pagar los ciudadanos. Si bien las cargas fiscales no fueron objeto de estudio específico por Santo Tomás, el Aquinate nos proporciona en la Summa Theologica un conjunto de principios básicos que pueden ser aplicados a dicha materia ${ }^{143}$ :

- Los tributos, como cualquier otra materia que sea objeto de la ley, deben cumplir un requisito teleológico: la consecución del bien co-

\footnotetext{
138 Santo Tomás De Aquino, Summa Theologica, II-II, q. 61, a. 1, cit., vol. 3, p. 511.

${ }^{139}$ De acuerdo con la fórmula democrática aludida en la Summa, la expresión «libertad», utilizada por Santo Tomás, debe interpretarse en la actualidad como «igualdad».

140 Santo Tomás de Aquino, Summa Theologica, II-II, q. 61, a. 2, c., pp. 512-513.

${ }^{141}$ Hervada, J., Introducción crítica al Derecho natural, Eunsa, Pamplona, 1994, pp. 46-48.

142 FinNIS, J., Ley Natural y Derechos Naturales, cit. pp. 203-204.

${ }^{143}$ Esta cuestión ha sido objeto de un detenido estudio por PÉREZ DE AYALA, J. L., La doctrina moral de Santo Tomás sobre los impuestos y las obligaciones de pagarlos, Valoración y significado desde una perspectiva social, CEU, Madrid, 2002.
} 
mún ${ }^{144}$. En consecuencia, sólo serán admisibles aquellas cargas fiscales que redunden en beneficio de la comunidad y no las que persigan otros objetivos bastardos como pueden ser, entre otros muchos, el enriquecimiento injusto del gobernante o el aseguramiento de una masa de fieles votantes favorecidos por los fondos públicos. Este criterio implica la necesidad de establecer una adecuada conexión entre los ingresos y los gastos del Estado, pues los primeros sólo se encuentran justificados en tanto que los segundos redunden en el bien común. En este sentido, el equilibrio y la eficiencia presupuestaria encuentran fácil acomodo en la doctrina tomista.

- El deber de contribuir obliga a todos los ciudadanos, de forma que no se atente contra el principio de universalidad tributaria ${ }^{145}$. La exigencia se funda en el presupuesto de que la consecución del bien común es una tarea que, al redundar en beneficio de todos, exige la colaboración de la comunidad en pleno. Ello justifica la interdicción de privilegios generales en la regulación de los impuestos y la persecución del fraude fiscal.

- Sin embargo, este deber general no conlleva forzosamente uniformidad. En efecto, dicha igualdad debe ser «proporcional» ${ }^{146}$, lo cual permite defender la distribución de las obligaciones tributarias teniendo en cuenta la capacidad económica de cada sujeto u otras circunstancias de carácter económico o personal que lo modulen. Con ello se justifica la existencia de distintas desgravaciones como las que atiendan al número de miembros de la unidad familiar, la aplicación de las rentas obtenidas a fines benéficos o la reinversión de beneficios en la actividad empresarial.

\footnotetext{
${ }^{144}$ Santo Tomás De Aquino, Summa Theologica, I-II, q, 90, a. 2, c., cit., vol. 2, p, 705: «... como la ley se constituye primariamente por el orden al bien común, cualquier otro precepto sobre actos particulares no tiene razón de ley sino en cuanto se ordena al bien común. Se concluye, pues, que toda ley se ordena al bien común».

$145 \mathrm{Ibid}$., I-II, q, 96, a. 4, c., p.751: «A su vez, las leyes pueden ser injustas... porque se oponen al bien humano al quebrantar cualquiera de las tres condiciones señaladas... [una de las cuales es] la de la forma, como cuando las cargas se imponen a los ciudadanos de manera desigual».

146 Santo Tomás DE Aquino, I-II, q. 96, a. 4, c., pp. 750-751: «... las leyes pueden ser justas... por razón de la forma, o sea, porque distribuyen las cargas con igualdad proporcional y en función del bien común. Pues el individuo humano es parte de la sociedad y, por la tanto, pertenece a ella en lo que es y con lo que tiene, de la misma manera que la parte, en cuanto tal, pertenece al todo... Por eso estas leyes que reparten las cargas proporcionalmente son justas, obligan en conciencia y son verdaderamente legales».
} 
Partiendo de la enseñanza de Santo Tomás y relacionando el sistema impositivo con la función social de la propiedad y los principios de justicia distributiva, FINNIS -en abierta polémica con NOZICK ${ }^{147}$ - defiende que la tributación constituye un deber fundado en exigencias de justicia, donde la intervención coactiva del Estado sólo debe actuar de forma subsidiaria.

De acuerdo con ello, el profesor australiano sostiene que, con carácter previo a las exacciones fiscales de los poderes públicos, deben tomarse en consideración dos circunstancias: primera, que el ciudadano goza de los elementos patrimoniales suficientes para hacer frente a sus necesidades básicas y, segunda, que el contribuyente no haya destinado voluntariamente lo que excede de dicho umbral a otros fines de utilidad social y beneficio común. Sólo en el caso de que no concurra ninguno de estos presupuestos, cabe considerar legítima la recaudación coactiva estatal respecto de los bienes de los particulares, legítimamente obtenidos, sobre la base del cumplimiento de la función social de la propiedad en su consideración de deber inherente a este derecho ${ }^{148}$.

Como corolario de lo expuesto, de la doctrina tomista se derivan tres consecuencias de singular trascendencia para la conformación del moderno Estado social:

- Hay supuestos en que la justicia no implica estrictamente igualdad, entendida ésta como igualitarismo homogeneizador.

- Los recursos públicos deben emplearse para atender, en primer término, situaciones de escasez suprema respecto de bienes primarios materiales y espirituales, imprescindibles para el pleno desarrollo de la persona $y$, una vez satisfechas éstas, tienen que ser aplicados a quienes necesiten de dichos bienes combinando los siguientes criterios: dependencia del sujeto en relación con estos recursos, aptitud para su aprovechamiento y justa correspondencia con la aportación económica de cada ciudadano.

- El sistema tributario se encuentra subordinado al bien común. Su realización práctica debe compaginar el principio de generalidad en la obligación impositiva, que comprende a todos los ciudadanos, y el de igualdad proporcional, atendiendo a las circunstancias económicas, sociales y particulares de cada contribuyente.

\footnotetext{
147 Nozick, R., Anarchy, State and Utopia, Basil Blackwell, Oxford, 1974, pp. 167-174, considera una radical injusticia que el Estado prive, de forma coactiva, a sus ciudadanos de aquellos bienes que han sido adquiridos por los mismos de acuerdo con el ordenamiento jurídico y con justo título, pues ello implica un auténtico robo con apariencia de legalidad que se asimila a los trabajos forzados.

148 FINNIS, J., Ley Natural y Derechos Naturales, cit., pp. 202, 214-216 y 220.
} 
Otra cuestión que surge en relación con este tipo de justicia sería determinar quién debe llevar a cabo dicha distribución, lo cual analizaremos en el siguiente apartado

\subsection{Principio de subsidiariedad}

La solución adoptada por el dominico en cuanto al protagonismo de la tarea distributiva constituye una prueba más de su ponderación y sentido del equilibrio: En un primer término, reconoce que la responsabilidad de dicha labor compete al titular del gobierno de la comunidad ${ }^{149}$, pero, por otro lado, también atribuye esta función a todos los integrantes de la sociedad que, en su propio ámbito, deben ser protagonistas de este proceso distributivo en cuanto titulares directos de un deber de justicia que no es monopolio del príncipe ${ }^{150}$.

Por tanto, el papel que desempeña el Estado, dentro del ámbito de sus funciones, se encuentra fuertemente limitado no sólo por su servicio a la justicia y a la ley racional, sino también al respeto a los distintos ámbitos del bien común a los que afecta ${ }^{151}$. De ahí que Santo Tomás distinga claramente entre el bien propio del individuo, el de la familia y el de la comunidad política ${ }^{152}$. Según ello, resulta imprescindible reconocer un importante ámbito

149 Ello debe relacionarse con las tres funciones a las que principalmente se encuentra llamado el príncipe. La primera es la consecución de la paz, la segunda fomentar la virtud en sus súbditos y, en tercer lugar, proporcionar a éstos últimos los bienes necesarios para su existencia, como se puede leer en Santo Tomás DE Aquino, De Regimine Principum, I, 15, cit., pp. 97-98.

150 Santo Tomás DE Aquino, Summa Theologica, II-II, q. 61, a. 1, ad. 3, cit., vol. 3, p. 511. Partiendo de la distinción del Doctor Angélico entre los distintos tipos de justicia, FINNIS, J., Ley Natural y Derechos Naturales, cit. pp. 213-214, señala que la justicia distributiva no constituye una misión exclusiva del Estado sino que, como parte de la justicia legal, es «la forma fundamental de toda justicia» e implica deberes tanto para el gobernante como para los ciudadanos, de ahí que el papel coactivo del poder político en materia tributaria sea «decisivo pero subsidiario».

${ }^{151}$ En cuanto a la distinción entre diversas clases de bien común, resulta interesante la aportación de Poole, D., «Bien Común y Derechos Humanos», Persona y Derecho, n. ${ }^{\circ} 59$ (2008), p. 111: «... el bien común político -lo que muchos intérpretes de Santo Tomás llaman el bien común sin más especificación- es aquella parte del bien común social integral que puede y debe ser promovido y tutelado por el Estado». Esta distinción entre el bien común político y el social integral, también puede apreciarse en FinNIs, J., Aquinas. Moral, Political and Legal Theory, cit., pp. 238239 , incidiendo en el carácter limitado e instrumental del primero frente a la generalidad del segundo.

152 Santo Tomás De Aquino, Summa Theologica, II-II, q. 47, a. 11, c., cit., vol. 3, p. 409. Desarrollando dicha doctrina, la relación entre las diversas esferas del bien común ha sido estudiada por FINNIs, J., Aquinas. Moral, Political and Legal Theory, cit., p. 251-252. «... los bienes privados 
de autonomía a otras entidades de carácter intermedio entre el individuo y el Estado, a las cuales corresponde una esfera propia de actuación que no puede ni debe ser invadida por el poder político, con mención especial al núcleo familiar ${ }^{153}$.

De esta forma aparece enunciado y definido, como reverso de la capacidad de los denominados «cuerpos intermedios» para gestionar preferentemente el ámbito que les resulta propio, el principio de subsidiariedad que restringe la intervención del Estado a aquellos asuntos que no pueden ser adecuadamente abordados por sus protagonistas inmediatos: la familia, los sindicatos, las corporaciones profesionales y asociaciones, agrupaciones vecinales, entidades sin ánimo de lucro, confesiones religiosas, etc. ${ }^{154}$.

La subsidiariedad ha tenido una importante repercusión en la actual configuración de las políticas públicas. Y no sólo como concepto teórico mantenido por el Magisterio pontificio ${ }^{155} \mathrm{y}$, consiguientemente, por los partidos de inspiración democristiana que protagonizaron el proyecto de reconstrucción continental tras la Segunda Guerra Mundial, sino también

pueden prevalecer sobre sobre el público u otro bien común; el legislador estatal no puede intervenir correctamente en las relaciones y transacciones privadas más que para salvaguardar la justicia y la paz; el bien individual, el bien común de la familia y el bien común del estado son irreductiblemente diversos; $y$ las personas privadas no necesitan que sus vidas sean exclusivamente vividas en función del bien del Estado y sus fines».

153 Santo Tomás de Aquino, Summa Theologica, II-II, q. 10, a. 12, ad. 2 y 3, vol. 3, pp. 123-124: «Por eso, tampoco puede nadie violar el orden natural, que pone al hijo bajo el cuidado del padre [...] y ésta [la obediencia civil de los súbditos respecto de los gobernantes] no excluye el orden del derecho natural ni del divino».

${ }^{154} \mathrm{Y}$ es que, como afirma Hervada, J., Introducción crítica al Derecho natural, cit., p. 56, la persona goza de una singularidad irreductible frente a la colectividad y, por ende, al Estado, de ahí que siempre deba existir una esfera -constituida por el haz de derechos naturales inherentes a todo ser humano y su desarrollo a través de diversas asociaciones o comunidades- exenta de la intervención estatal.

${ }^{155} \mathrm{La}$ formulación del principio de subsidiariedad ya aparece, principalmente en defensa de la familia, de forma implícita en LEÓN XIII, Rerunm Novarum, 15 de marzo de 1891, 10, y explícitamente dirigido a un ámbito social más amplio en Pío XI, Quadragesimo Anno, 15 de mayo de 1931, 80. No obstante, ya se podía rastrear un primer atisbo en LEÓN XIII, Inmortale Dei, 1 de diciembre de 1885, 19: «Los monumentos históricos de las edades precedentes demuestran que la Iglesia católica ha sido siempre la iniciadora, o la impulsora, o la protectora de todas las instituciones que pueden contribuir al bienestar común en el Estado. Tales son las eficaces instituciones creadas para coartar la tiranía de los príncipes que gobiernan mal a los pueblos; las que impiden que el poder supremo del Estado invada indebidamente la esfera municipal o familiar...». Todos estos textos pontificios pueden consultarse en la página web de la Santa Sede $<$ www.vatican.va $>$. 
como uno de los pilares fundamentales en la construcción jurídica de la Unión Europea ${ }^{156}$.

Pero es que, además, este principio resulta imprescindible para una adecuada comprensión del Estado social y, de este modo, evitar su degeneración en un Estado «asistencial» que termine coartando la libertad de la sociedad civil y los derechos de los ciudadanos. La omnipresencia del poder político, que tiende a confundir lo público -ese «interés público» tan invocado como erróneamente entendido- con la Administración o la actividad estatal, dejando un margen residual a la iniciativa de la sociedad civil en la esfera social, constituye uno de los peligros más graves que corremos en el momento presente.

En efecto, considerar que el Estado social implica, forzosamente, el monopolio estatal de servicios tales como la enseñanza, la sanidad o la asistencia social, hasta el extremo de convertirlos en servicios públicos donde la iniciativa privada -siempre controlada por una omnipresente burocracia- sea una mera comparsa, constituye una simplificación interesada y, lo que es peor, un extraordinario error que conlleva los siguientes peligros:

- Se desmovilizan iniciativas de la sociedad civil que, legítimamente y en el ámbito de sus propios intereses, podrían desarrollar una excelente labor para la efectiva realización de los derechos sociales ${ }^{157}$. Como consecuencia de lo anterior, se impide a diversos colectivos participar directamente en la gestión de lo público. Con ello se des-

${ }^{156}$ Artículo 5 del Tratado de la Unión Europea (DOE n. ${ }^{\circ}$ 83, de 30 de marzo de 2010). Al respecto, Herrero y RodrígueZ DE MiÑón, M., «Tratado de la Unión Europea y Constitución española: el principio de subsidiariedad», Anales de la Real Academia de Ciencias Morales y Políticas, n. ${ }^{\circ} 70$ (1993), pp. 359-377, estudia la aplicación de este principio en el Derecho comunitario. En el análisis de su evolución histórica, este autor omite toda referencia al Doctor Angélico, entendiendo que la primera formulación puede rastrearse en Bodino, alcanzando su plena madurez con Althusio. Asimismo, insiste en la existencia de tres corrientes doctrinales que han dado lugar a su actual concreción jurídica: el iusnaturalismo neotomista católico, la filosofía social calvinista y el federalismo organicista alemán.

157 Contreras, F. J., «La crítica liberal del estado del Bienestar», Liberalismo, catolicismo y ley natural, Encuentro, Madrid, 2011, pp. 259-260: «La Historia... confirma que la sociedad civil puede asumir con éxito la responsabilidad asistencial, siempre que sus iniciativas no se vean desplazadas y asfixiadas por por la del Estado. En la segunda mitad del siglo XIX y las primeras décadas del XX proliferaron en muchos países occidentales friendly societies, cooperativas, mutualidades profesionales, etc. que dispensaban a sus miembros atención médica de calidad a un precio razonable. La mayor parte de los trabajadores llegaron a estar cubiertos por alguna de estas entidades [...] El Estado [a través de la afiliación obligatoria de trabajadores con salarios bajos a la Seguridad Social británica, impuesta por la National Insurance Act (1911)], por tanto, desplazó a este tipo de entidades, arrebatándoles su misión y su clientela». 
perdicia, además de un importante capital humano, la oportunidad de obtener una mayor implicación de los ciudadanos en el orden constitucional ${ }^{158}$.

- El coste económico de un Estado sufragador de las necesidades reales o ficticias -recordemos que las mismas no cesan de incrementarse en una sociedad hedonista y relativista que carezca de fuertes referentes morales- demandadas por todos sus componentes, desde el momento de su nacimiento hasta el de su muerte, resulta inabordable desde la perspectiva presupuestaria.

- La lógica del incremento progresivo del intervencionismo estatal implica, además, un inquietante déficit democrático. El gobernante, haciendo un uso indebido de los recursos económicos que obtiene de los tributos pagados por los ciudadanos, cae fácilmente en la tentación demagógica de utilizarlos para generar una importante bolsa de beneficiaros de ayudas públicas y asegurarse, de este modo, amplios nichos de clientelismo político o $\ll$ voto cautivo ${ }^{159}$.

A modo de resumen, podríamos decir que el pensamiento tomista sirve para configurar la subsidiariedad como el principio estructural adecuado -o «forma»- que debe adoptar el Estado social -entendido éste último como «materia» moldeable- para la consecución del fin que le es propio: la tutela del bien común entendido como la justa relación entre el interés general y los derechos fundamentales de los ciudadanos.

${ }^{158}$ Aún esta por de hacer, en nuestro país, un análisis riguroso sobre la actual configuración del Estado «asistencial» como una de las causas de la actual crisis de la democracia occidental, debido a la transferencia de responsabilidad que ello implica en los ciudadanos, quienes dejan en manos de burócratas la gestión de lo público y cada vez se sienten más alejados de la toma de decisiones. Sobre el concepto de la «externalización de responsabilidad» del individuo al Estado, vid. SchmidTz, D. y Goodin, D., Social Welfare and Individual Responsibility, Cambridge University, Press, Cambridge, 1998.

159 Siguiendo a SANTO Tomás DE AQUINO, Summa Theologica, I-II, q. 96, a. 4, c. cit., vol. 2, p. 751, podemos afirmar que este uso desviado de los recursos públicos constituye un supuesto de leyes injustas por el fin que persiguen, ya que se imponen obligaciones a los ciudadanos que no están dirigidas a la atención del bien común sino hacia el exclusivo provecho del gobernante. Al respecto, resultan tristemente proféticas las palabras de LOCKE, J., Segundo Tratado sobre el Gobierno Civil, cit., n.222, p. 213: «También actúa en contra de lo que se le ha encomendado [el máximo titular del gobierno] cuando emplea la fuerza, el tesoro y los servicios de la sociedad para corromper a los representantes de ésta y ganárselos para sus propios fines; o cuando abiertamente coacciona a los electores... Este controlar a los candidatos y a los electores; este amañar los sistemas de elección, ¿qué son sino un tajar las raíces mismas del gobierno, envenenando así la fuente de la seguridad pública?». 


\section{Conclusiones}

- La afirmación de que todos los principios básicos del gobierno político contemporáneo se encontraban literalmente recogidos en la doctrina de Santo Tomás constituye, sin duda, un evidente anacronismo histórico. No obstante, muchas de sus aportaciones, desarrolladas a través de los siglos, resultaron decisivas para la posterior consolidación del moderno Estado constitucional democrático.

- El Estado de Derecho, como el ejercicio del poder sometido al principio de legalidad, tiene perfecta cabida en la definición del Aquinate de la ley como una prescripción de la razón dirigida al bien común, ya que prescindir de dichos elementos implica injusticia y tiranía.

- En la Summa Theologica puede apreciarse una rudimentaria división de poderes. Especialmente, en su consideración del régimen mixto como sistema ideal que combina distintos estamentos sociales, a los cuales les competen, como funciones distintas, las de legislar, elegir a los gobernantes y asesorar en la toma de decisiones. Sin embargo, el control jurisdiccional del poder político aún no aparece diseñado en los términos propios del Estado contemporáneo.

- Propiamente, el santo dominico no contiene en sus obras la expresión ni el concepto de los modernos derechos humanos, en tanto que no contempla la idea de derecho subjetivo como potestad o facultad individual sino el ius, propio del Derecho romano clásico, como relación de equilibrio y justicia. Sin embargo, Santo Tomás desarrolló determinados principios que fueron imprescindibles para el posterior nacimiento de tales derechos: la superior e inviolable dignidad humana, la limitación del poder político por la ley natural y la posibilidad, en caso extremo y bajo ciertas condiciones, de deponer al gobernante despótico.

- El Doctor Angélico defiende que el poder se ejerza por el príncipe en su condición de delegado o representante del pueblo, asumiendo una función vicaria, con lo cual admite la concurrencia de un importante elemento democrático en su teoría política. Sin embargo, esta concepción dista mucho de la «voluntad general» de Rousseau en tanto que las decisiones de la mayoría están sujetas a ciertos límites, como la ley natural y la eterna. En este sentido, se aproxima al Estado constitucional democrático que defiende la suprema posición jurídica de los derechos fundamentales y, por tanto, la sumisión del poder legislativo al contenido esencial de las libertades públicas y a las decisiones del Tribunal Constitucional. 
- Aunque la opinión doctrinal mayoritaria mantenga una radical incompatibilidad entre el contrato social, propio de los pensadores ilustrados, y la concepción comunitario-organicista de la sociedad, subyacente en las teorías aristotélico-tomistas, dicha conclusión debe ser revisada o, al menos, matizada. No hay una identidad total entre ambas, pero la contradicción puede salvarse. Para ello, debe entenderse que la sociabilidad constituye un rasgo natural inherente a la condición humana, implicando la necesidad de que los distintos miembros de la comunidad lleguen a un acuerdo sobre la fórmula de gobierno más adecuada en cada momento histórico.

- Santo Tomás considera la propiedad privada como un derecho natural pero, realizando una distinción entre la facultad de gestión y la de uso, mantiene la necesidad de que los bienes sean utilizados en beneficio de la comunidad. Con ello sienta un claro precedente de la actual configuración de la función social de la propiedad prevista en la mayoría de las constituciones vigentes.

- Basándose en los principios de justicia, se reconoce por el Aquinate la obligación de realizar determinadas actuaciones que impliquen una distribución no homogénea de los recursos entre los individuos, atendiendo a sus particulares circunstancias entre las que se incluyen las necesidades de subsistencia material. Ello, unido al imperativo del gobernante de procurar para sus súbditos los medios imprescindibles para su sustento, constituyen el germen del Estado social.

- Sin embargo, la intervención del Estado debe respetar el ámbito de autonomía propio de la ciudadanía, ya que tanto los individuos como las familias gozan de una esfera de bien común que le es propia y no debe ser invadida por el poder público, salvo en el caso de absoluta imposibilidad de ser correctamente atendida por sus titulares. Éste es el embrión del principio de subsidiariedad, que en la actualidad ha tenido importantes desarrollos en la normativa europea, y, a su vez, sirve de eficaz antídoto contra los peligros de la degeneración del Estado social en un Estado-providencia o asistencial con siniestros tintes «orwellianos». 